\section{Dilkaya (Orta Çağ) İnsanlarının Sağlık Yapısı}

\author{
Serkan ŞAHIIN ${ }^{1 *} \odot$
}

${ }^{1}$ Dr. Öğr. Üyesi. Kırşehir Ahi Evran Üniversitesi, Fen - Edebiyat Fakültesi, Antropoloji Bölümü, Kırşehir / TÜRKIYE
* Sorumlu Yazar / Corresponding Author: Serkan ŞAHIN Kırşehir Ahi Evran Üniversitesi, Fen - Edebiyat Fakültesi, Antropoloji Bölümü, Kırşehir / TÜRKIYE E-posta: serkansahin@ahievran.edu.tr Alındı/Received: 24 Ocak / January 2019 Düzeltildi/Revised: 25 Nisan / April 2019 Kabul/Accepted: 29 Nisan / April 2019 Erken Görünüm / Early View: 7 Mayıs / May 2019 Yayımlanma/Published: 12 Haziran / June 2019

The Health Status of (Medieval) Dilkaya People

\section{Öz}

$\mathrm{Bu}$ çalışmanın materyalini oluşturan iskelet kalıntıları Van/Dilkaya kazılarından elde edilmiştir. Dilkaya Höyüğü Van'ın Edremit ilçesine bağlı Dilkaya Köyü’nün batısında Van Gölü kıyısında yer almaktadır. Çalışmanın amacı Dilkaya Orta Çağ Toplumu'nun patolojik olarak incelenmesi ve elde edilen verilerin diğer Anadolu toplumlarıly karşılaştırılması sonucunda toplumun sağlık yapısının belirlenmesidir. Dilkaya toplumunda 319 birey paleopatolojik açıdan incelenmiş ve topluluğun yaşam biçimi ortaya çıkarılmaya çalışılmıştır. Toplumda en az bir omurunda osteartrit görülen erişkinlerin oranı \%82,05'dir. Toplumda en az bir omurunda schmorl nodülü görülen erişkinlerin oranı ise \%89,74'tür. Erişkin bireylerin eklemlerinde osteoartrit görülme oranı \%52,56'dır. Dilkaya OrtaÇağ Toplumunda en az bir ekleminde ya da omurunda yaşam biçimine bağlı olarak gelişen patoloji görülen erişkin bireylerin topluma oranı \%97,44’tür. Omurlarda ve eklemlerdeki yaşam biçimine bağlı olarak gelişen patolojiler en fazla erkek bireylerde gözlemlenmiş ve görülme oranının yaşla birlikte artış gösterdiği belirlenmiştir. Patolojik lezyonların her yaş/cinsiyet grubunu etkilemesi, enfeksiyonel hastalıkların fazla görülmemesi ve osteoartritin genç yaşlardan itibaren görülmeye başlanması gibi verilerden hareketle Dilkaya Orta Çağ Toplumu'nun tarıma dayalı bir ekonomiye sahip, beslenme açısından görece iyi durumda ve diğer Anadolu toplumlarına kıyasla göreceli olarak daha hijyenik yaşam koşullarına sahip bir köy topluluğu olduğu düşünülmektedir.

Anahtar Sözcükler: Paleopatoloji, Orta Çağ, Sağlık Yapısı, Doğu Anadolu

\section{Giriş}

İran, Kafkasya, Mezopotamya ve Orta Anadolu'nun merkezinde yer alan Doğu Anadolu Bölgesi maden ve yeraltı kaynakları açısından zengin bir bölgedir ve bu zenginliği birçok uygarllğa ev sahipliği yapmasını sağlamıştır. Doğu Anadolu'yu kendilerine yurt edinen insanlar Erken Demir Çağı'nda (M.Ö. 1300-850) bölgede örgütlenerek kaleler kurmuss ve daha sonra Urartu Kralliğ1 adı altında bir araya gelmişlerdir (Belli ve Konyar, 2003).

\section{Abstract}

The remains composing the material of this study are obtained from Van/Dilkaya excavations. Dilkaya Mound is located at the west of Dilkaya village of Van's Edremit province, near the coast of Lake Van. The aim of this study is to investigate pathological structure of medieval population of Dilkaya and to use this data in identification of health structure as well making a comparison with other Anatolian populations. A total of 319 individuals in Dilkaya medieval people were examined in terms of paleopathology and estimations about the life style of the population were made. The ratio of the adults which have osteoarthritis at least in one vertebral bone is $82,05 \%$. Similarly, the ratio of adults which have schmorl nodules at least in one vertebral bone is $89,74 \%$. Moreover, 52,56\% of the adults show osteoarthritis in their joints. In Medieval Population of Dilkaya, the ratio of adult individuals who had lifestyle related pathology in at least one vertebral bone or joint is 97,44\% while most of the lifestyle related pathologies in the vertebral bones and joints are observed in males and it was observed that the pathology increases with age. Due to the fact that pathological lesions affect all age/gender groups; small amount of the population have infectious diseases and the presence of osteoarthritis is observed since younger ages; the Medieval Population of Dilkaya is concluded to be a village population of agricultural economy. Moreover, the nutrition and the bygienic conditions were shown to be relatively better than other Anatolian Populations.

Key Words: Paleopathology, Medieval, Health Status, East Anatolia

Doğu Anadolu Bölgesi'nin insan yașamı açısından en verimli bölümü ise Van Gölü Havzası'dır. Bölge yeraltı kaynakları açısından zengin olmasına rağmen sert bir karasal iklime sahiptir ve etrafinda bulunan sıradağlar nedeniyle Karadeniz ve Akdeniz'den gelebilecek ılımanlaştırıcı etkiden mahrum kalmaktadır. Bu bölgede yerleşik düzene geç geçilmesinin temel nedeni olumsuz iklim koşullarıdır. Kalkolitik dönemden hemen önce Van Gölü kenar çizgisinin bugünkü seviyesinden 350 $\mathrm{m}$ daha içeridedir. Bu durum bölgenin o dönemde 
günümüze göre daha kurak ve tarıma elverişsiz olduğunu gösteren önemli bir kanıttır (Sevin ve Kavakl1, 1996; Belli ve Konyar, 2003; Köroğlu ve Konyar, 2005, 2008).

Van Gölü Havzası'nda bölgedeki Demir Çağ1 yerleşimini gösteren üç önemli höyük kazısı yapılmıştır: Dilkaya Höyüğü, Van Kalesi Höyüğü ve Karagündüz Höyüğü. Her üçünde de Karaz veya Erken Transkafkasya türü çanak çömlekler bulunmuştur. Yine her üç yerleşim yerinde bulunan yapılar kerpiçten mekanlardır ve Orta Demir Çağı'na tarihlendirilirler. Bu höyüklerde M.Ö 2. Binyıl ve Erken Demir Çağı mimari tabaka olarak bulunmamaktadır (Köroğlu ve Konyar, 2005, 2008). Bu durum Van Gölü Havzası'nda yaşayan toplulukların Orta Demir Çağı'ndan önce göçebe olduklarını göstermektedir. Bölgede yaşam dönemdeki zor iklim koşulları nedeniyle temelde hayvancıllı̆ga ve höyüklerin etrafinda yapılan kuru tarıma dayalıdır. Sulama faaliyetlerine ise kuraklık nedeniyle henüz geçilememiştir (Çilingiroğlu, 1994, 1997).

Van Gölü Havzası'ndaki höyük kazıları sayesinde elde edilen 3. ve 2. binyıla ait arkeolojik malzemenin yeterli olmayışı bu çağlarla ilgili sağlıklı sonuçlara varılmasını engellemiştir. Bölgede yapılan Urartu kazıları ise tümüyle Urartu döneminde inşa edilen kalelerde gerçekleştirilmiştir. Bu nedenle erken Urartu tarihi ve Urartu kültürünün kökeni ile ilgili birçok sorun aydınlatılamamışır. Dilkaya kazılarına yukarıda değinilen sorunların çözülebilmesi amacıyla 1984 yılında başlanmıştır (Çilingiroğlu, 1986).

Araştırma konusunu meydana getiren Dilkaya Höyüğü’nde ilk insan yerleşimi MÖ 2500-2300 y1lları arasındadır. Höyük Erken Tunç Çağında terk edilmiş daha sonraki dönemlerde Erken Demir Çağı'nda yerleşim görmüş ve yine terk edilmiş ve en son Orta Çağ'da insan yerleşimine tanık olmuş ve terk edilmiş bir iskân alanıdır (Çilingiroğlu, 2012). Dilkaya Höyügüüyle alakalı yapılan paleoantropolojik çalışmaların yanında bu çalışma Dilkaya ve çevresinde farklı dönemlerde yaşamış ve iskeletlerine ulaşılabilen insanlar arasındaki olası ilişkiler nelerdir, beslenme, göç, ekonomik durum ve çevresel faktörlerin insan sağllğına nasıl bir etkisi olur gibi sorulara cevaplar bulmaya çalışarak Van Gölü Havzası'nda geçmişte yaşamıs insanların nasıl bir hayat yaşadıkları konusunda karanlıkta kalan kısımları aydınlatabilmeyi amaçlamıştır.

\section{Gereç ve Yöntem}

Dilkaya kazıları, Ege Üniversitesi, İstanbul Üniversitesi, Van Müzesi ve Van Bölgesi Tarih ve Arkeoloji Araştırmaları Merkezi'nin ortaklığında Urartu kültürü ve tarihini araştırmak üzere gerçekleştirilen "Van
Gölü Havzası Projesi" kapsaminda Prof. Dr. Altan Çilingiroğlu başkanlığındaki ekip tarafindan 1984-1991 yılları arasında gerçekleştirilmiştir (Çilingiroğlu, 1993: 469). Dilkaya Höyüğü ve Nekropolü, Van'ın Edremit ilçesine bağlı Edremit Köyü'nün batısında Van Gölü kıyısında yer almaktadır ve Van'dan $24 \mathrm{~km}$ uzaklıktadır (Çilingiroğlu, 1986). Höyük (Resim 1, 2, 3) Hoşap Suyu'nun Van Gölü’ne döküldüğü yerde doğal bir kumul yükselti üzerinde bulunmaktadır (Çilingiroğlu, 1990).

Araştırma konusunu meydana getiren Dilkaya Höyüğü’nde ilk insan yerleşimi MÖ 2500-2300 y1lları arasındadır. Erken Tunç Çağı'nda terk edilmiş olan Höyük, daha sonra Erken Demir Çağı'nda tekrar yerleşim görüp yine terk edilmiş ve en son Orta Çağ'da insan yerleşimine tanık olmuş bir iskân alanıdır (Çilingiroğlu, 2012). Çalışma materyalini oluşturan iskelet kalıntıları Prof. Dr. Altan Çilingiroğlu başkanlığında 1984-1991 yılları arasinda yapilan Van/Dilkaya kazılarından elde edilmiştir. Dilkaya toplumunu oluşturan iskeletlerin paleodemografik incelemeleri Ankara Üniversitesi Dil ve Tarih - Coğrafya Fakültesi Paleoantropoloji Anabilim Dalı Enver Yaşar Bostancı ve Refakat Çiner Laboratuvarı'nda gerçekleştirilmiştir ve topluma ait toplam 319 birey tespit edilmiştir (Tablo 1) (Güleç, 1986; Güleç, 1989; Güleç ve Özer, 2009).
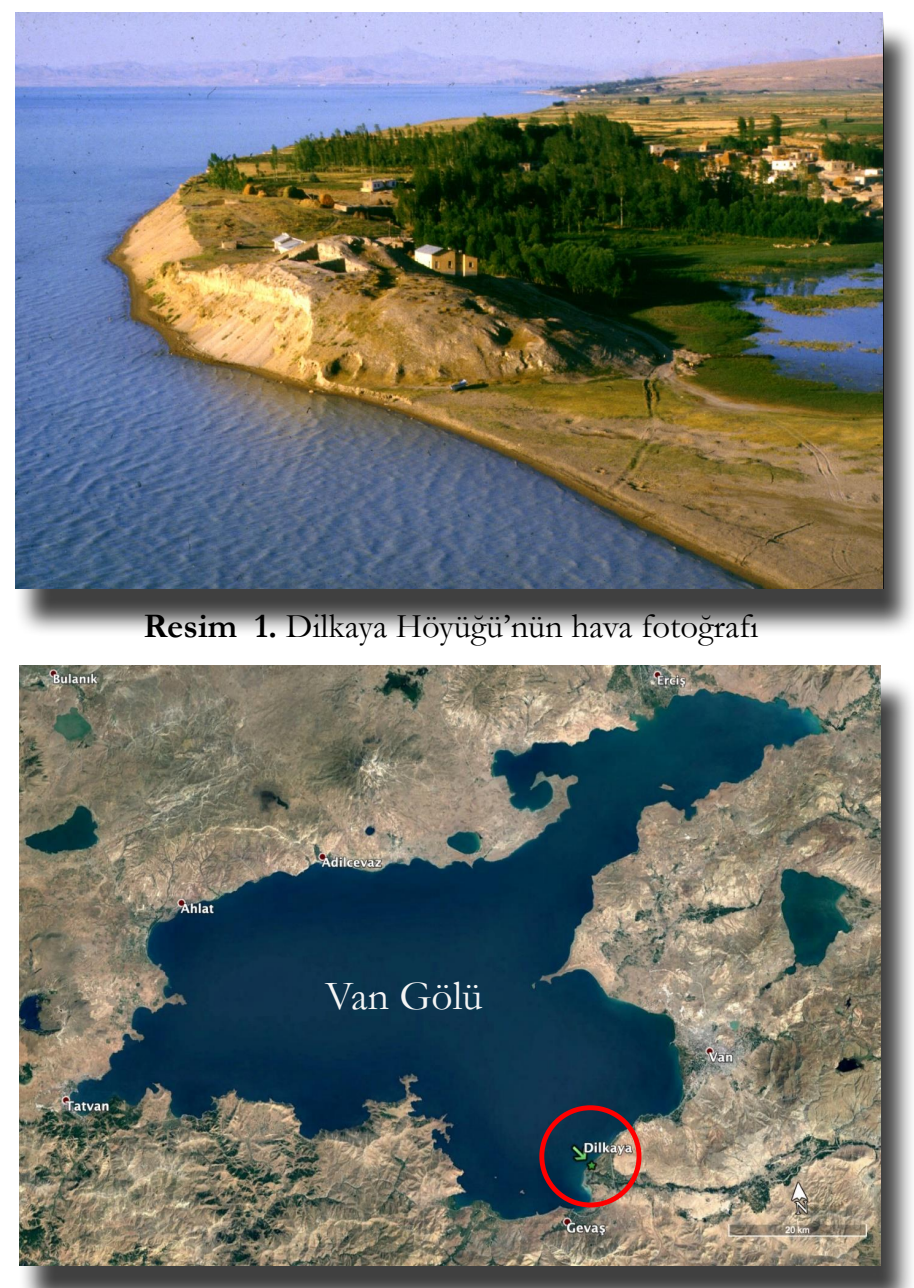

Resim 2. Dilkaya Höyügü’nün konumu (kırmızı halka) 


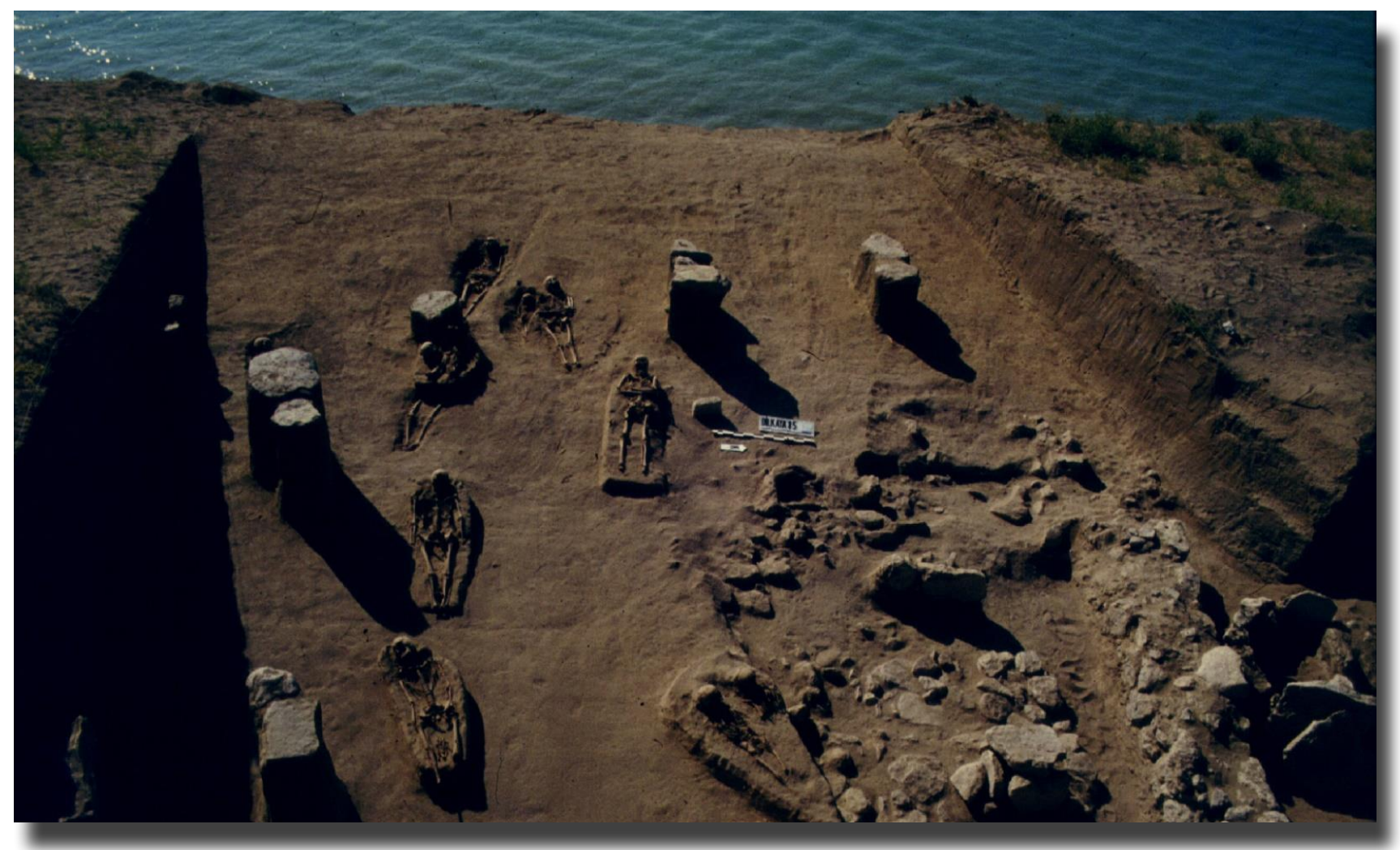

Resim 3. Kum mezarlar (Dilkaya Kazı Arşivi)

\section{Cinsiyet, Yaş ve Paleodemografik Belirlenmesi}

Dilkaya Orta Çağ Toplumu üzerindeki paleodemografik ve morfolojik incelemeler Prof. Dr. Erksin Güleç ve Prof. Dr. İsmail Özer tarafindan yapılmıştır (Güleç, 1986; Güleç ve Özer, 2009).

\section{Patolojilerin Belirlenmesi}

Paleopatolojik lezyonlar belirlenirken Brothwell (1981), Buikstra ve Ubelaker (1994), Lovell (1994, 1997, 2008); Ortner (2003), Aufderheide ve Rodriguez-Martin (2006), Roberts ve Manchester (2007), Brickley ve Ives (2008), Waldron (2009), Mann ve Hunt (2012), Mann vd., (2016) ve Buikstra (2019)'da belirtilen tanımlamalardan yararlanılmıştır. Elde edilen paleopatolojik veriler üzerinde SPSS 22 programı yardımıyla ki-kare dağılım $\left(\chi^{2}\right.$ dağılımı) testi yapılmış ve cinsiyetler arasındaki farklılıklar saptanmaya çalışılmıştır (Plichta ve Kelvin, 2014).

Tablo 1. Dilkaya Orta Çă̆ Toğlumu'nun demografik dağılımı (Güleç ve Özer, 2009)

\begin{tabular}{ccc}
\hline Demografik Dağılım & $\mathbf{N}$ & $\mathbf{\%}$ \\
\hline Bebek (0 - 2,5 yaş) & 51 & 15,99 \\
Çocuk (2,5 - 18 yaş) & 112 & 35,11 \\
Kadın (18 yaş üzeri) & 74 & 23,20 \\
Erkek (18 yaş üzeri) & 82 & 25,70 \\
Toplam & $\mathbf{3 1 9}$ & $\mathbf{1 0 0}$ \\
\hline
\end{tabular}

\section{Bulgular}

\section{Yaşam Biçimine Bağlı Anomaliler}

Geçmişte yaşamış insan toplulukları paleopatolojik olarak incelendiğinde, yaşam biçimlerini ortaya çıkarma açısından en iyi ipuçlarını, yaşam boyu iskelet yapılarında meydana gelen değissimler verir. İlerleyen yaş, enfeksiyonel hastalıklar ve kalıtsal bozukluklar gibi birçok etmenin etkili olduğu bu değişimlere neden olan rahatsizlıklar ise, osteoartrit, omurgada gözlemlenen eklem rahatsızlıkları, travma ve çeşitli entesopatilerdir.

\section{a) Osteoartrit}

Dilkaya Toplumunda periferal osteoartrit $\% 58,53$ ile en fazla erkek bireylerde gözlemlenmiştir ve yaşla beraber osteoartrit görülme oranı artmaktadır. Cinsiyetler arasındaki farklılık istatiksel olarak anlamlıdır $(p<0,01$ $\left.=6,64, \chi^{2}: \mathbf{6 , 6 7} ; \mathrm{sd}: 1\right)$. Genç erişkinlerde osteoartrit görülme oranı $\% 24$ iken yaşlılarda bu oran \%62,77'ye çıkmaktadır (Tablo 2, 3). Toplumda periferal osteoartrit en fazla ön kol kemiklerinde görülmüştür. Eklemlerde en fazla osteoartrit sirasiyla dirsek eklemi, omuz eklemi ve kalça ekleminde gözlemlenmektedir (Resim 4).

\section{b) Enstosopatiler}

Entesopatik oluşumlara kadınlarda \%14,86, erkeklerde ise $\% 35,37$ oranında rastlanmıştır. Toplumda entesopati en fazla erkek bireylerde gözlemlenmiştir ve görülme oranı yaşla beraber artmaktadır. Cinsiyetler arasındaki farkllık istatiksel olarak anlamlıdır $(\mathrm{p}<0,02=5.41$, 
$\chi^{2}: 5.91$, sd: 1). Genç erişkinlerde entesopati görülme oranı $\% 4$ olmasına rağmen yaşlılarda bu oran $\% 31,91$ 'e çıkmaktadır (Tablo 2, 3). Toplumda entesopatilere en çok femur ve tibiada rastlanmıştır.

\section{c) Ankilozan Spondilitis ve DISH}

Dilkaya toplumunda üç bireyin omurlarında ankilozan spondilitise rastlanmıştır. Bu bireylerin ikisi erkek biri kadındır. 45 yaşın üzerindeki erkek bireyin sakrumu ve L5, L4, L3 omurları birbirleriyle kaynaşmıştır; bireyin sakrumunda iyileşmiş bir kırık bulunmaktadır. Muhtemelen bu kaynaşmanın oluşum sebebi travma sonras1 komplikasyonlardır. Ankilozan spondilitis gözlemlenen diğer erkek birey ise 52 yaşındadır. $\mathrm{Bu}$ bireyin de T7-12 numaralı omurları birbiriyle kaynaşmıştır. Ankilozan spondilitis gözlemlenen son birey 57 yaşında bir kadındır ve onun da sakrumu ile L5 ve L4 omurları kaynaşmıştır (Resim 5). Kadın bireylerde ankilozan spondilitis görülme oran1 \%1,61, erkek bireylerde ise $\% 3,51$ 'dir. Toplumun genelinde ise bu oran \%2,52'dir (Tablo 2, 3).

Toplumda sadece bir erkek bireyin omurlarında DISH'e rastlanmıştır. 57 yaşıı üzerinde olan bu bireyin T9-12 isimli omurları birbirleriyle kaynaşmışır; bireyin sakrumunda ve lumbar omurlarında ve eklemlerinde bir hayli osteofit oluşumu; alt üyelerinde ise yoğun şekilde entesopati gözlemlenmiştir (Resim 6). Erkek bireylerde DISH görülme oranı \%1,75'tir. Toplumun genelinde ise bu oran \%0,84 olarak tespit edilmiştir (Tablo 2, 3).

\section{d) Rhomboid Fossa}

Rhomboid fossa toplumda \%23,73 ile en fazla erkek bireylerde gözlemlenmiştir. Cinsiyetler arasındaki farklılık istatiksel olarak anlamsızdır $\left(p<0,1=2,71, \chi^{2}\right.$ : 2,70, sd:1). Bireylerde rhomboid fossa görülme oranı yaşla birlikte artmaktadır (Tablo 2, 3).

\section{e) Spondylolysis}

Toplumda spondylolysis \%11,48 ile en fazla kadin bireylerde gözlemlenmiştir. Cinsiyetler arasındaki farklılik istatiksel olarak anlamsizdır $\left(\mathrm{p}<0,1=4,61, \chi^{2}\right.$ : 1,98, sd: 2). Spondylosisin genç erişkinlerde görülme oranı ise \%15,79'dur (Tablo 2, 3).

\section{f) Distal Femoral Cortical Excavation (DFCE)}

DFCE, Dilkaya toplumunda \%33,33 ile en fazla erkek bireylerde gözlemlenmiştir ve yaşa bağlı olarak artış göstermektedir (Tablo 2,3). Cinsiyetler arasındaki farkl1lı istatiksel olarak anlamlıdır $(\mathrm{p}<0,001=10,83$, $\chi^{2}: 16,54$, sd: 1) (Resim 7).

\section{g) Vertebral Osteofit}

Vertebral osteofite Dilkaya toplumunda en çok lumbar omurlarda rastlanmıştır. Toplumda vertebral osteofit tüm omur bölgelerinde en fazla erkek bireylerde gözlemlenmiştir ve yaşla beraber görülme oranı artmaktadır (Tablo 2, 3). Cinsiyetler arasındaki farkl1lik istatiksel olarak servikal ve lumbar omurlarda anlamliyken torakal omurlarda anlamsızdır. İstatiksel analizler sonucunda servikal omurlarda, $(\mathrm{p}<0,1=2,71$, $\chi^{2}: 3,70$, sd: 1$)$, torakal omurlarda $\left(\mathrm{p}<0,1=2,71 \chi^{2}: 1,15\right.$, sd: 1$)$ ve lumbar omurlarda $\left(\mathrm{p}<0,1=2,7,1 \chi^{2} \mathbf{2} \mathbf{2 , 9 9}\right.$, sd: 1$)$ değerleri elde edilmiştir.

\section{h) Apofizyal Osteoartirit}

Toplumda apofizyal osteoartrite tüm omur bölgelerinde en fazla erkeklerde rastlanmıştır görülme oranı yaşla beraber artmaktadır (Tablo 2, 3). Cinsiyetler arasındaki farklılık istatiksel olarak servikal ve lumbar omurlarda anlamliyken torakal omurlarda anlamsızdır. İstatiksel analizler sonucunda servikal omurlarda, $(\mathrm{p}<0,1=2,71$, $\chi^{2}: 2,74$, sd: 1$)$, torakal omurlarda $\left(\mathrm{p}<0,1=2,71, \chi^{2}\right.$ : $2,10$, sd: 1$)$ ve lumbar omurlarda $\left(\mathrm{p}<0,1=2,71, \chi^{2}: \mathbf{3}, \mathbf{7 7}\right.$, sd: 1) değerleri elde edilmiştir.

\section{i) Schmorl Nodülü}

Dilkaya Toplumunda schmorl nodülüne servikal omurlarda kadın bireylerde daha fazla, torakal ve lumbar omurlarda ise erkek bireylerde daha fazla rastlanmıştır ve yaşla beraber görülme oranı artmaktadır (Tablo 2, 3). Cinsiyetler arasındaki farklılık istatiksel olarak servikal, torakal ve lumbar omurlarda anlamsızdır. İstatiksel analizler sonucunda servikal omurlarda, $(\mathrm{p}<0,1=2,71$ $\chi^{2}: 0,26$, sd: 1$)$, torakal omurlarda $\left(\mathrm{p}<0,1=2,71, \chi^{2}\right.$ : $0,64$, sd: 1$)$ ve lumbar omurlarda $\left(p<0,1=2,71, \chi^{2}: 1,46\right.$, sd: 1) değerleri elde edilmiştir.

\section{j) Travma}

Sağlik ve sosyal durumlar göz önüne alındığında paleopatolojik açıdan önemli bir veri kaynağı olan travma kafatası ve post-cranial olmak üzere iki başlık altında incelenmiştir.

\section{- Cranial Travmalar}

Dilkaya toplumunda sadece yedi bireyde kafatas1 travmasına rastlanmıştır. Bu bireylerden altısı erkek, biri kadındir. Kafatası travması tespit edilen DK'85 AHT 13 numaralı 37 yaşındaki erkek bireyin kafatasının sol kısmında, orbital kenardan başlayarak frontal boyunca devam eden ve parietalin orta kisminda sona eren muhtemelen kesici bir alet tarafindan yapılmış bir kesik izi tespit edilmiştir. Ayrıca bireyin sol zygomatic 


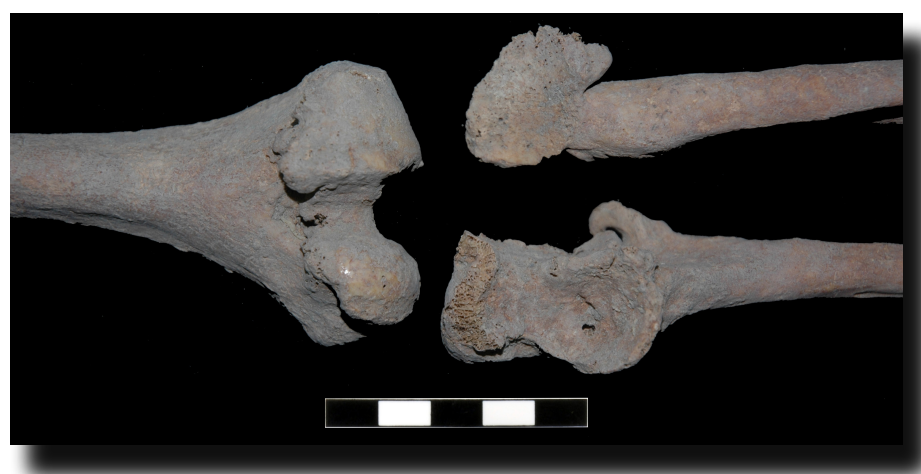

Resim 4. DK'89 BTT 26 (57-60 yas) numaralı kadın birevin sol humerus distali, sol ulna ve sol radius proximalinde görülen osteoartrit

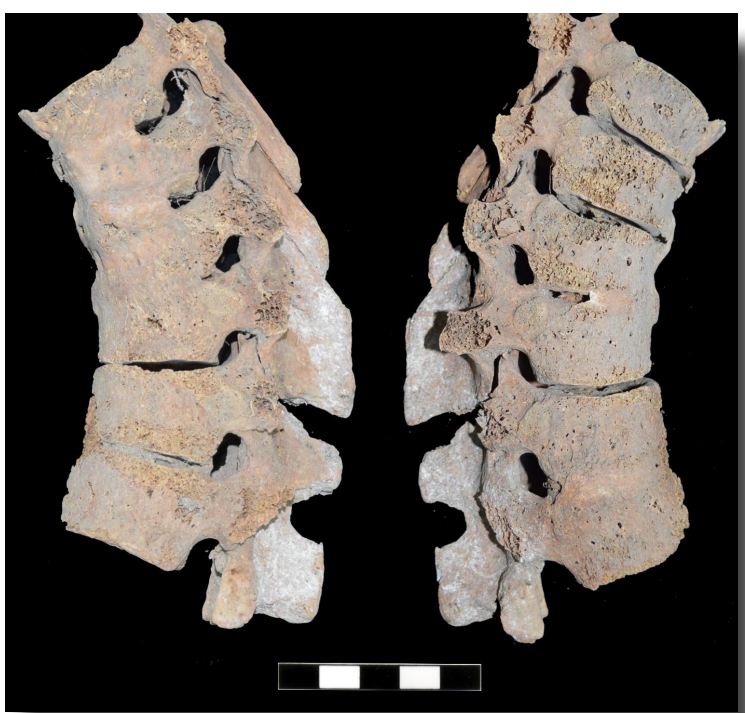

Resim 5. DK'89 BTD 11 (52-55 yaș) numaralı erkek bireyde gözlemlenen ankilozan spondilitis

arc bölgesi de bu travma sonucu yok olmuştur. Bunun sonucu olarak bireyin sol parietalinden occipitaline doğru olan bölgede 4 santimetre çapında daire şeklinde bir kısım kesilerek çıkartılmıştır. Birey muhtemelen yüz yüze çarpışma esnasında kafatasının sol tarafina büyük bir kesici aletle darbe almıştır. Bireyin sol radiusunun distal kisminda da muhtemelen savunma kaynaklı bir kesik izi bulunmaktadır ve bireyde gözlemlenen travmalarda iyileşme belirtisi bulunmamaktadır.

Kafatas1 travmas1 tespit edilen DK'85 AHU 14 numaralı 20-25 yaşlarında erkek bireyin frontalinde iki orbital arasında muhtemelen darbeye bağlı kemik çöküntüsü gözlemlenmiştir. Occipitalin sagittal sutura kadar olan kısmı dikdörtgen şeklinde kesilmiştir ve occipital çıkarılmıştır. Bireyde gözlemlenen travmalarda iyileșme belirtisi bulunmamaktadır.

DK'89 BTM 20 numaralı 67 yaşlarında erkek bireyin kafatasının sağparieatal kısmından temporal ve occipitale doğru devam eden iyileşmiş bir kırık gözlemlenmiştir (Resim 8). Ayrıca sağ ulnasının distalinde ve sağ birinci metacarpalinde kırık tespit edilmiştir. Bireyde

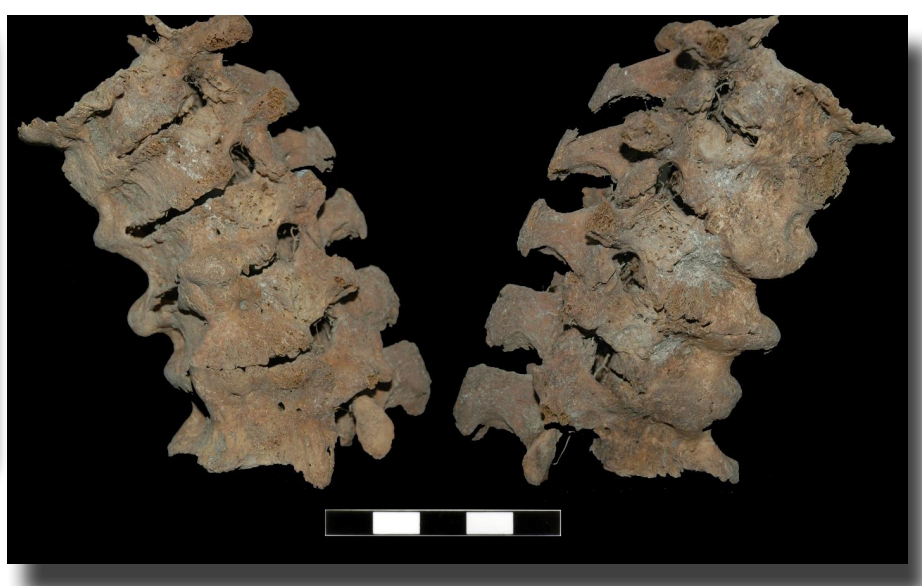

Resim 6. DK'89 BYD 50 (52 yaş) numaralı erkek bireyin torakal omurlarında gözlemlenen DISH

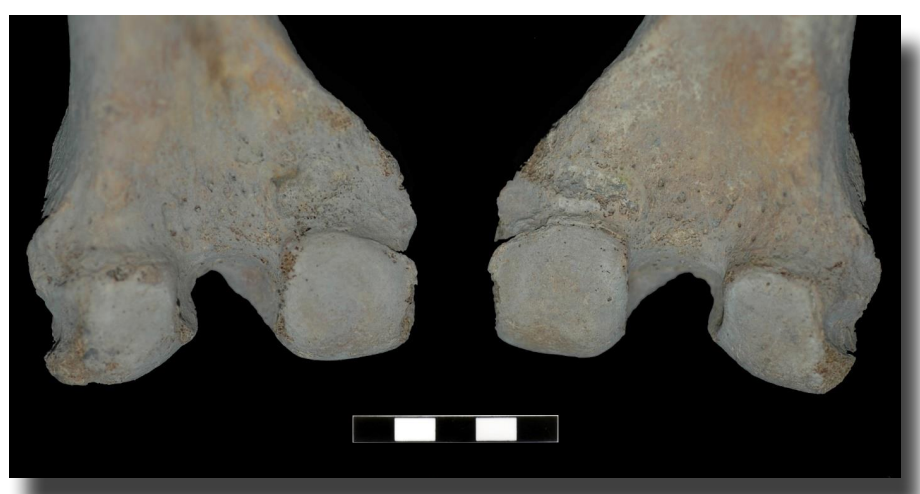

Resim 7. DK'89 BTS 25 numaralı erkek bireye (53-55 yass) ait femurda görülen "Distal Femoral Cortical Excavation"

gözlemlenen kırıklar muhtemelen yüksek bir yerden düşme sonucu ortaya çıkmıştır. Dilkaya toplumunda gözlemlenen diğer kafatası travmaları 1-2 santimetre çapında darbeye bağlı küçük çöküntüler şeklindedir ve hepsi bireyin yaşamı esnasında iyileşmiştir.

Toplumda kafatas travmalar1 \%9,09 ile en fazla erkek bireylerde gözlemlenmiştir. Cinsiyetler arasındaki farklılık istatiksel olarak anlamlidır $\left(\mathrm{p}<0,1=2,71, \boldsymbol{\chi}^{2}\right.$ : $\underline{\mathbf{3}, \mathbf{6 9}}$, sd:1). Tespit edilen kafatas1 travmaların neredeyse \%70’i yaşlı bireylerde gözlemlenmiştir (Tablo 2, 3).

\section{- Post-cranial Travmalar}

Dilkaya toplumunda gözlemlenen gövde travmalarına genelde uzun kemiklerde rastlanmıştır ve travmaların tamamı bireyin yaşamı esnasında iyileşmiştir. Tümü erkek bireylerde gözlemlenen bu travmaların, 2'si claviculada, 1'i radiusta, 2'si ulnada ve 1'i coxada gözlemlenmiştir.

Toplumda post-cranial travmalar \% $\%, 31$ ile sadece erkek bireylerde gözlemlenmiştir. Cinsiyetler arasındaki farklılık istatiksel olarak anlamlıdır $\left(p<0,02=5,41, \boldsymbol{\chi}^{2}\right.$ : $\underline{\mathbf{5}, \mathbf{6 3}}$, sd: $1 ;$ ). Genç erişkin bireylerde post-cranial travma gözlemlenmezken orta erişkin ve yaşlı bireylerde postcranial travma görülme oranı birbirine yakındır (Tablo $2,3)$. 


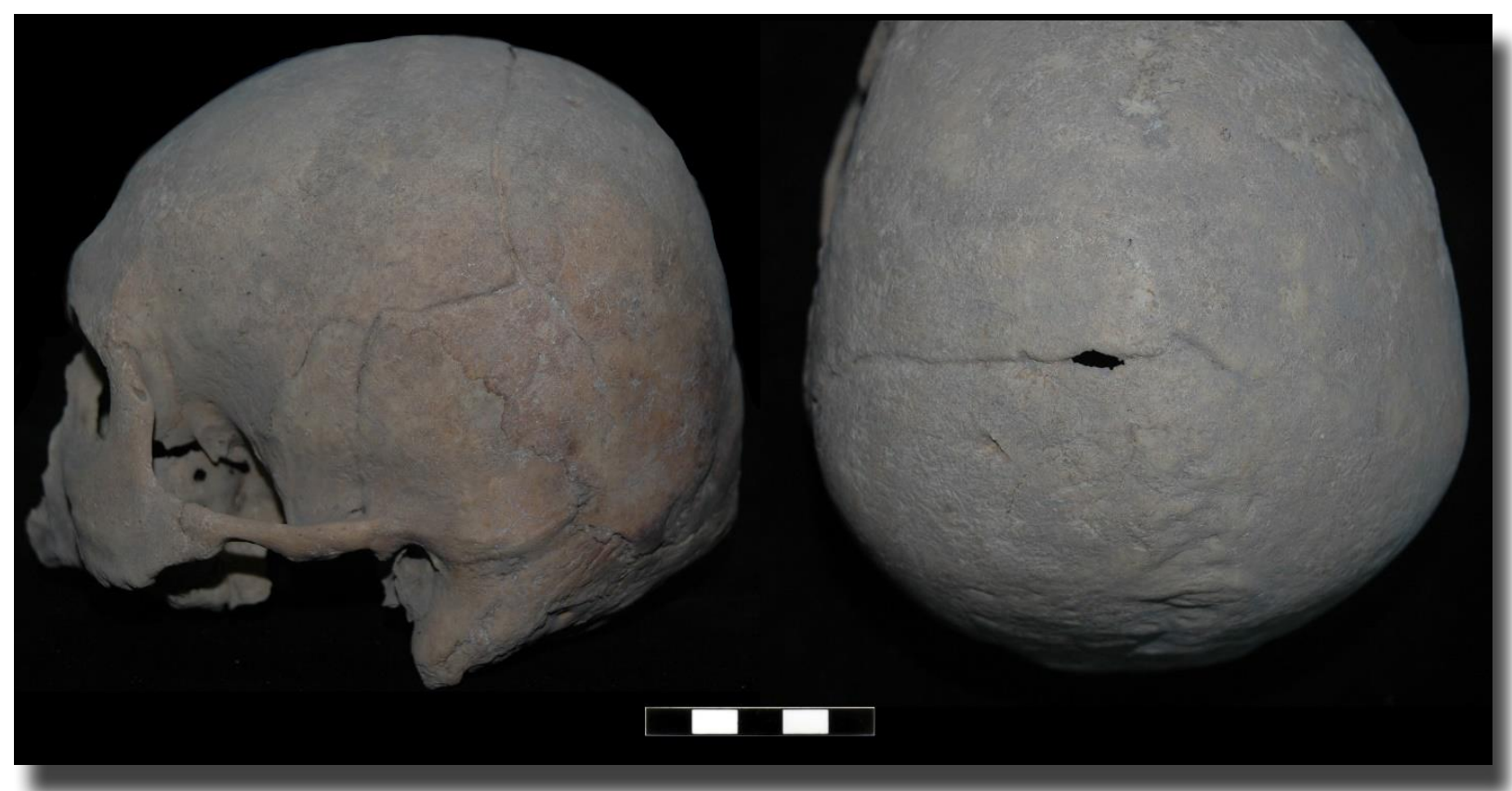

Resim 8. DK'89 BTM 20 numaralı erkek bireye (67-70 yaş) ait kafatasında görülen "travma"

\section{Metabolik Hastalıklar}

Metabolik hastalıklar eski insan topluluklarının yaşam biçimlerini ortaya çıkarmakta araştırmacılara ipuçları sağlayan bir başka veri grubudur. Beslenme eksikliği ya da bozukluğu, vitamin eksiklikleri gibi durumların sonucu olarak bireylerin kemik yapılarında değişimler meydana gelir. Bu değişimlere sebep olan rahatsızlıklar, anemi, iskorbüt, osteomalasi, raşitizm gibi hastalıklardır (Ortner, 2003).

\section{a) Cribra Orbitalia ve Porotic Hyperostosis}

Cribra orbitalia, Dilkaya toplumunda \%26,98 ile en fazla 4-10 yaş arasındaki çocuk bireylerde gözlemlenmiştir ve görülme sıklığ1 yaşa bağlı olarak azalmaktadır. (Tablo $2,3)$. Cinsiyetler ve yaş grupları arasındaki farklılık istatiksel olarak anlamlıdır $\left(\mathrm{p}<0,001=16,27, \boldsymbol{\chi x}^{\mathbf{2}} \mathbf{2 1 , 5 7}\right.$, sd: 3). Porotic hyperostosis de $\% 2,22$ ile en fazla çocuk bireylerde gözlemlenmiştir. Cinsiyetler ve yaş grupları arasındaki farklılık istatiksel olarak anlamsızdır $(\mathrm{p}<0,1=$ $\left.\mathbf{6 , 2 5} \chi^{2}: 2,01, \mathrm{sd}: 3\right)$. Porotic hyperostosis lezyonu görülen bireylerde ayrıca diploe kalınlaşmasına rastlanmamıştır.

\section{b) D Vitamini Eksikliği}

Dilkaya toplumunda D vitamini eksikliğine bağlı deformasyonlar $\% 5,36$ oran ile en çok çocuklarda gözlemlenmiştir (Tablo 2,3). Cinsiyetler ve yaş grupları arasındaki farklılık istatiksel olarak anlamlıdır $(\mathrm{p}<0,1=$ $6,25, \chi^{2}: \mathbf{6}, 47$, sd: 3$)$.

\section{Konjenital Anomaliler}

Doğuştan anomaliler veya sakatliklar intrauterin (rahim içi) yaşam boyunca, normal gelişim sürecinde ortaya çıan patolojik değişimlerdir. Bu anomaliler doğum esnasında veya sonrasında gözlemlenebilir (Aufderheide ve Rodriguez-Martin, 2006).

\section{a) Spina Bifida}

Spina bifida anomalisi toplumda \%14,81 ile en fazla kadınlarda gözlemlenmiştir. Cinsiyetler arasındaki farkl1lık istatiksel olarak anlamsızdır $\left(\mathrm{p}<0,1=4,61, \chi^{2}\right.$ : 0,391, sd: 2) (Tablo 2, 3).

\section{b) Sakral Agenezi}

Sakral agenezi (Resim 9) anomalisi Dilkaya toplumunda $\% 13,33$ ile en fazla çocuk bireylerde gözlemlenmiştir (Tablo 2, 3). Cinsiyetler ve yaş grupları arasındaki farklılık istatiksel olarak anlamsızdır $\left(\mathrm{p}<0,1=4,61, \chi^{2}\right.$ : 3,29, sd: 2).

\section{c) Sakralizasyon}

Sakralizasyon anomalisi toplumda \%25 ile en fazla erkek bireylerde gözlemlenmiştir ancak cinsiyetler arasındaki farklılık istatiksel olarak anlamsızdır (Tablo 2, 3) $(\mathrm{p}<0,1$ $=4,61, \chi^{2}: 2,89$, sd: 2 ).

\section{d) Çoklu Blok Vertebra}

Toplumda çoklu blok vertebra anomalisi servikal omurlarda \%4,76 ile en fazla erkek bireylerde gözlemlenmiştir (Resim 10). Torakal omurlarda ise \%6,25 ile yine en fazla erkek bireylerde gözlemlenmiştir (Tablo 2,3). Servikal omurlarda kaynaşma en çok üç bireyde axis ve 3. servikal (C3) omurlarda görülürken bir bireyde C3 ve C4 arasında gerçekleşmiştir. Torakal omurlarda ise bir bireyde T1-T2, iki bireyde T2-T3 ve bir bireyde T6-T7 arasında gerçekleşmiştir. 
Şahin |Antropoloji 37 (2019): 50-71

Tablo 2. Dilkaya toplumunda hastalıkların cinsiyet gruplarına göre dağılımı

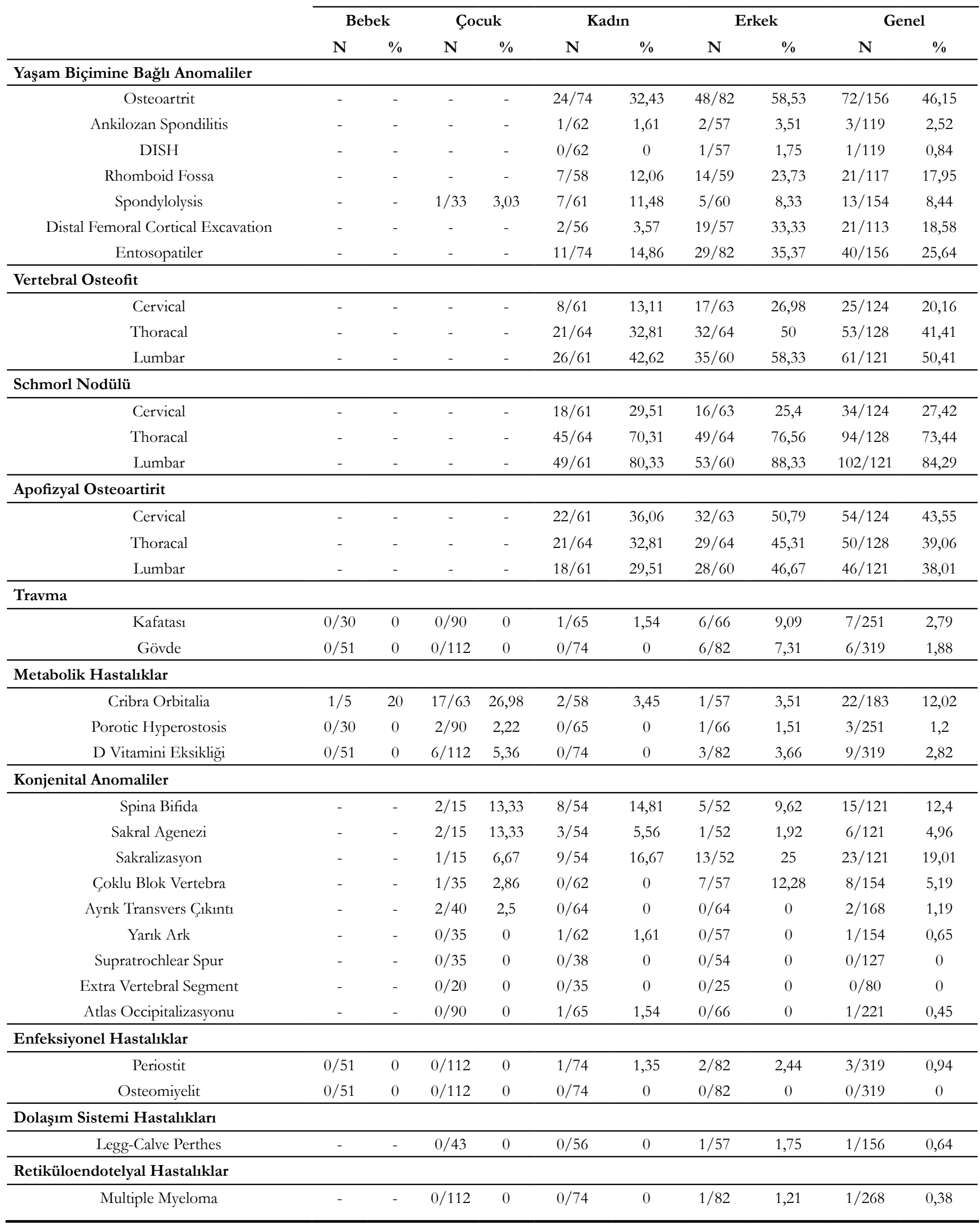


Şahin |Antropoloji 37 (2019): 50-71

Tablo 3. Dilkaya toplumunda hastalıkların yaş gruplarına göre dağılımı

\begin{tabular}{|c|c|c|c|c|c|c|c|c|c|c|c|c|}
\hline & \multicolumn{2}{|c|}{ Bebek } & \multicolumn{2}{|c|}{ Çocuk } & \multicolumn{2}{|c|}{ Genç Erişkin } & \multicolumn{2}{|c|}{ Orta Erişkin } & \multicolumn{2}{|c|}{ Yaşl1 } & \multicolumn{2}{|c|}{ Genel } \\
\hline & $\mathbf{N}$ & $\%$ & $\mathbf{N}$ & $\%$ & $\mathbf{N}$ & $\%$ & $\mathbf{N}$ & $\%$ & $\mathbf{N}$ & $\%$ & $\mathbf{N}$ & $\%$ \\
\hline \multicolumn{13}{|l|}{ Yaşam Biçimine Bağlı Anomaliler } \\
\hline Osteoartrit & - & - & - & - & $6 / 25$ & 24 & $7 / 37$ & 18,91 & $59 / 94$ & 62,77 & $72 / 156$ & 46,15 \\
\hline Ankilozan Spondilitis & - & - & - & - & $0 / 16$ & 0 & $0 / 30$ & 0 & $3 / 73$ & 4,11 & $3 / 119$ & 2,52 \\
\hline DISH & - & - & - & - & $0 / 16$ & 0 & $0 / 30$ & 0 & $1 / 73$ & 1,37 & $1 / 119$ & 0,84 \\
\hline Rhomboid Fossa & - & - & - & - & $2 / 19$ & 10,52 & $5 / 27$ & 18,52 & $14 / 71$ & 19,72 & $21 / 117$ & 17,95 \\
\hline Spondylolysis & - & - & $1 / 33$ & 3,03 & $3 / 19$ & 15,79 & $2 / 26$ & 7,69 & $7 / 76$ & 9,21 & $13 / 154$ & 8,44 \\
\hline Distal Femoral Cortical Excavation & - & - & - & - & $0 / 20$ & 0 & $3 / 27$ & 11,11 & $18 / 66$ & 27,27 & $21 / 113$ & 18,58 \\
\hline Entosopatiler & - & - & - & - & $1 / 25$ & 4 & $9 / 37$ & 24,32 & $30 / 94$ & 31,91 & $40 / 156$ & 25,64 \\
\hline \multicolumn{13}{|l|}{ Vertebral Osteofit } \\
\hline Cervical & - & - & - & - & $0 / 20$ & 0 & $2 / 21$ & 9,52 & $23 / 83$ & 27,71 & $25 / 124$ & 20,16 \\
\hline Thoracal & - & - & - & - & $1 / 21$ & 4,76 & $7 / 26$ & 26,92 & $45 / 81$ & 55,56 & $53 / 128$ & 41,41 \\
\hline Lumbar & - & - & - & - & $1 / 19$ & 5,26 & $10 / 26$ & 38,46 & $50 / 76$ & 65,79 & $61 / 121$ & 50,41 \\
\hline \multicolumn{13}{|l|}{ Schmorl Nodülü } \\
\hline Cervical & - & - & - & - & $1 / 18$ & 5,56 & $4 / 25$ & 16 & $29 / 81$ & 35,80 & $34 / 124$ & 27,42 \\
\hline Thoracal & - & - & - & - & $10 / 21$ & 47,62 & $16 / 22$ & 72,72 & $68 / 85$ & 80 & $94 / 128$ & 73,44 \\
\hline Lumbar & - & - & - & - & $11 / 19$ & 57,89 & $22 / 26$ & 84,62 & $69 / 76$ & 90,79 & $102 / 121$ & 84,29 \\
\hline \multicolumn{13}{|l|}{ Apofizyal Osteoartirit } \\
\hline Cervical & - & - & - & - & $4 / 20$ & 20 & $7 / 21$ & 33,33 & $43 / 83$ & 51,81 & $54 / 124$ & 43,55 \\
\hline Thoracal & - & - & - & - & $5 / 21$ & 23,81 & $5 / 26$ & 19,23 & $40 / 81$ & 49,38 & $50 / 128$ & 39,06 \\
\hline Lumbar & - & - & - & - & $3 / 19$ & 15,79 & $6 / 26$ & 23,07 & $37 / 76$ & 48,68 & $46 / 121$ & 38,01 \\
\hline \multicolumn{13}{|l|}{ Travma } \\
\hline Kafatas 1 & $0 / 30$ & 0 & $0 / 90$ & 0 & $1 / 21$ & 4,76 & $1 / 34$ & 2,94 & $5 / 76$ & 6,58 & $7 / 251$ & 2,79 \\
\hline Gövde & $0 / 51$ & 0 & $0 / 112$ & 0 & $0 / 25$ & 0 & $2 / 37$ & 5,41 & $4 / 49$ & 4,26 & $6 / 319$ & 1,88 \\
\hline \multicolumn{13}{|l|}{ Metabolik Hastalıklar } \\
\hline Cribra Orbitalia & $1 / 5$ & 20 & $17 / 63$ & 26,98 & $0 / 21$ & 0 & $2 / 28$ & 7,14 & $2 / 66$ & 3,03 & $22 / 183$ & 12,02 \\
\hline Porotic Hyperostosis & $0 / 30$ & 0 & $2 / 90$ & 2,22 & $0 / 21$ & 0 & $0 / 34$ & 0 & $1 / 76$ & 1,32 & $3 / 251$ & 1,2 \\
\hline D Vitamini Eksikliği & $0 / 51$ & 0 & $6 / 112$ & 5,36 & $1 / 25$ & 4 & $1 / 37$ & 2,7 & $1 / 94$ & 1,06 & $9 / 319$ & 2,82 \\
\hline \multicolumn{13}{|l|}{ Konjenital Anomaliler } \\
\hline Spina Bifida & - & - & $2 / 15$ & 13,33 & $3 / 15$ & 20 & $2 / 25$ & 8 & $8 / 66$ & 12,12 & $15 / 121$ & 12,4 \\
\hline Sakral Agenezi & - & - & $2 / 15$ & 13,33 & $1 / 15$ & 6,67 & $2 / 25$ & 8 & $1 / 66$ & 1,52 & $6 / 121$ & 4,96 \\
\hline Sakralizasyon & - & - & $1 / 15$ & 6,67 & $3 / 15$ & 20 & $5 / 25$ & 20 & $14 / 66$ & 21,21 & $23 / 121$ & 19,01 \\
\hline Çoklu Blok Vertebra & - & - & $1 / 35$ & 2,86 & $0 / 16$ & 0 & $1 / 30$ & 3,33 & $6 / 73$ & 8,22 & $8 / 154$ & 5,19 \\
\hline Ayrık Transvers Çıkıntı & - & - & $2 / 40$ & 2,5 & $0 / 21$ & 0 & $0 / 27$ & 0 & $0 / 90$ & 0 & $2 / 168$ & 1,19 \\
\hline Yarık Ark & - & - & $0 / 35$ & 0 & $0 / 16$ & 0 & $0 / 30$ & 0 & $1 / 73$ & 1,37 & $1 / 154$ & 0,65 \\
\hline Supratrochlear Spur & - & - & $0 / 35$ & 0 & $0 / 16$ & 0 & $0 / 17$ & 0 & $0 / 59$ & 0 & $0 / 127$ & 0 \\
\hline Extra Vertebral Segment & - & - & $0 / 20$ & 0 & $0 / 6$ & 0 & $0 / 11$ & 0 & $0 / 43$ & 0 & $0 / 80$ & 0 \\
\hline Atlas Occipitalizasyonu & - & - & $0 / 90$ & 0 & $0 / 21$ & 0 & $0 / 34$ & 0 & $1 / 76$ & 1,32 & $1 / 221$ & 0,45 \\
\hline \multicolumn{13}{|l|}{ Enfeksiyonel Hastalıklar } \\
\hline Periostit & $0 / 51$ & 0 & $0 / 112$ & 0 & $0 / 25$ & 0 & $1 / 37$ & 2,7 & $2 / 94$ & 2,13 & $3 / 319$ & 0,94 \\
\hline Osteomiyelit & $0 / 51$ & 0 & $0 / 112$ & 0 & $0 / 25$ & 0 & $0 / 37$ & 0 & $0 / 94$ & 0 & $0 / 319$ & 0 \\
\hline \multicolumn{13}{|l|}{ Dolaşım Sistemi Hastalıkları } \\
\hline Legg-Calve Perthes & - & - & $0 / 43$ & 0 & $0 / 20$ & 0 & $0 / 27$ & 0 & $1 / 66$ & 1,52 & $1 / 156$ & 0,64 \\
\hline \multicolumn{13}{|l|}{ Retiküloendotelyal Hastalıklar } \\
\hline Multiple Myeloma & - & - & $0 / 112$ & 0 & $0 / 25$ & 0 & $0 / 37$ & 0 & $1 / 94$ & 1,06 & $1 / 268$ & 0,38 \\
\hline
\end{tabular}




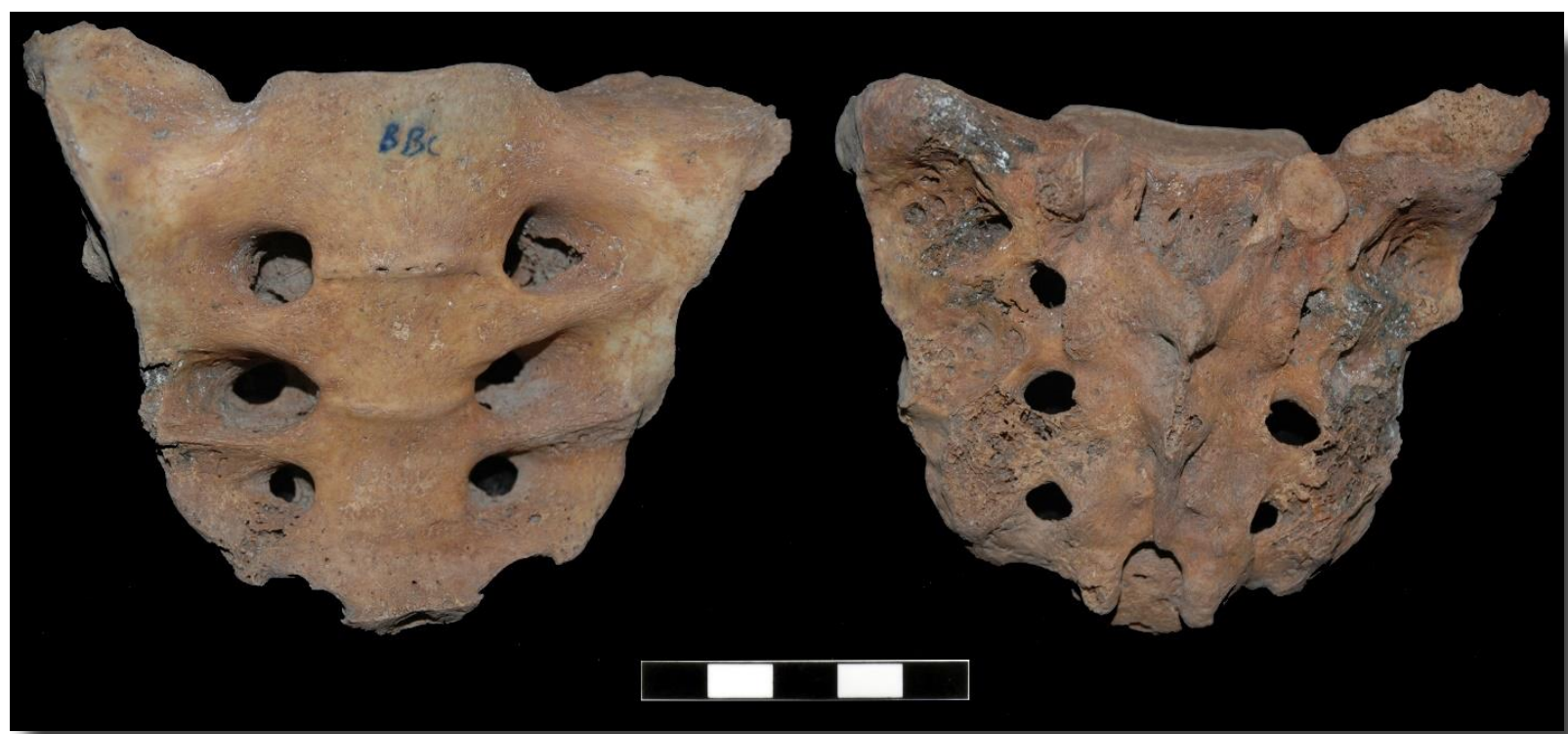

Resim 9. DK'87 BBC 39 numaralı bireye (53-55 yaş, kadın) ait sakrumda "sakral agenezi"

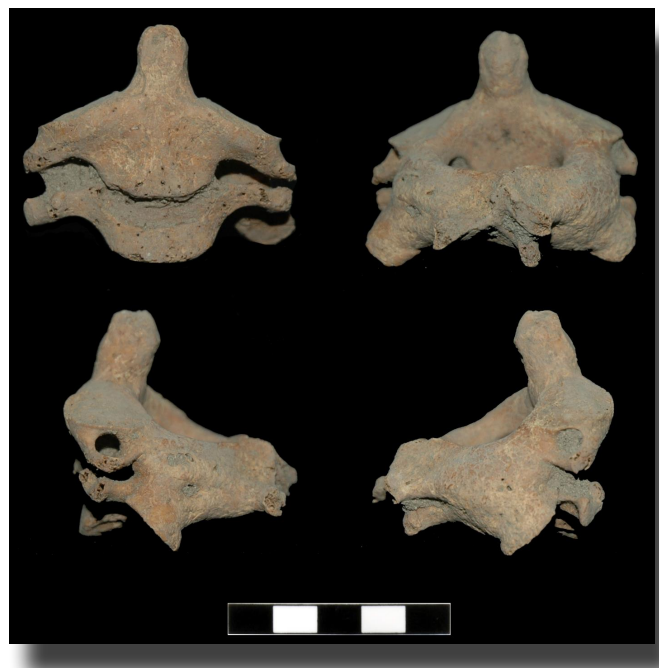

Resim 10. DK'89 BTL 19 numaralı bireye (9 - 9,5 yaş) ait axis ve 3. servikal omurda "çoklu blok vertebra" anomalisi

\section{e) Ayrık Transvers Çıkıntı}

Toplumda ayrı transvers çıkıntı anomalisine sadece torakal ve lumbar omurlarda rastlanılmıştır. Erişkin bireylerde ise bu anomaliye rastlanmamıştır. İncelenen çocuk bireylerin torakal omurlarında ayrı transvers çıkınt1 anomalisi görülme sılkl̆ğ \%2,5'dir. Toplumun genelinde ise bu oran \%1,19'dur (Tablo 2, 3).

\section{f) Yarık Ark}

Dilkaya toplumunda yark ark anomalisine sadece servikal omurlarda rastlanılmıştır. İncelenen çocuk ve erkek bireylerde yarı ark anomalisine rastlanmamıştır (Resim 11). Kadın bireylerde ise bu anomaliye rastlanma oran1 $\% 1,61$ 'dir. Toplumun genelinde ise bu oran $\% 0,65$ olarak hesaplanmıştır (Tablo 2, 3).

\section{g) Atlas Occipitalizasyonu}

Toplumda incelenen çocuk ve erkek bireylerde atlas occipitalizasyonu gözlemlenmezken, sadece bir kadın bireyde atlas occipitalizasyonuna rastlanmışı ır (Resim 12). Kadın bireylerde atlas occipitalizasyonu görülme oran1 $\% 1,54$ 'dir. Toplumun genelinde ise bu oran $\% 0,45$ olarak hesaplanmıştır (Tablo 2, 3).

\section{Enfeksiyonel Hastalıklar}

Antibiyotiğin keşfinden önce yaşayan toplumlarda enfeksiyonel hastalıkların savaş, kuraklık doğal afetler gibi felaketlerden daha fazla insan ölümüne neden olduğu düşünülmektedir (Roberts ve Manchester, 2007). Sadece kronik olan enfeksiyonel oluşumlar kemik üzerindetespit edilebilirler ve nedenlerine göre spesifik ve non-spesifik olmak üzere ikiye ayrllirlar. Bakterilerin yol açtı̆̆ cüzzam, tüberküloz ve frengi gibi hastalıklar spesifik olarak değerlendirilirken virüsler, bakteriler, mantarlar, parazitler ve mikroorganizmalar yoluyla gelişen hastaliklar non-spesifik olarak değerlendirilmektedir (Ortner, 2003).

Dilkaya toplumunda sadece üç bireyin kemiklerinde 


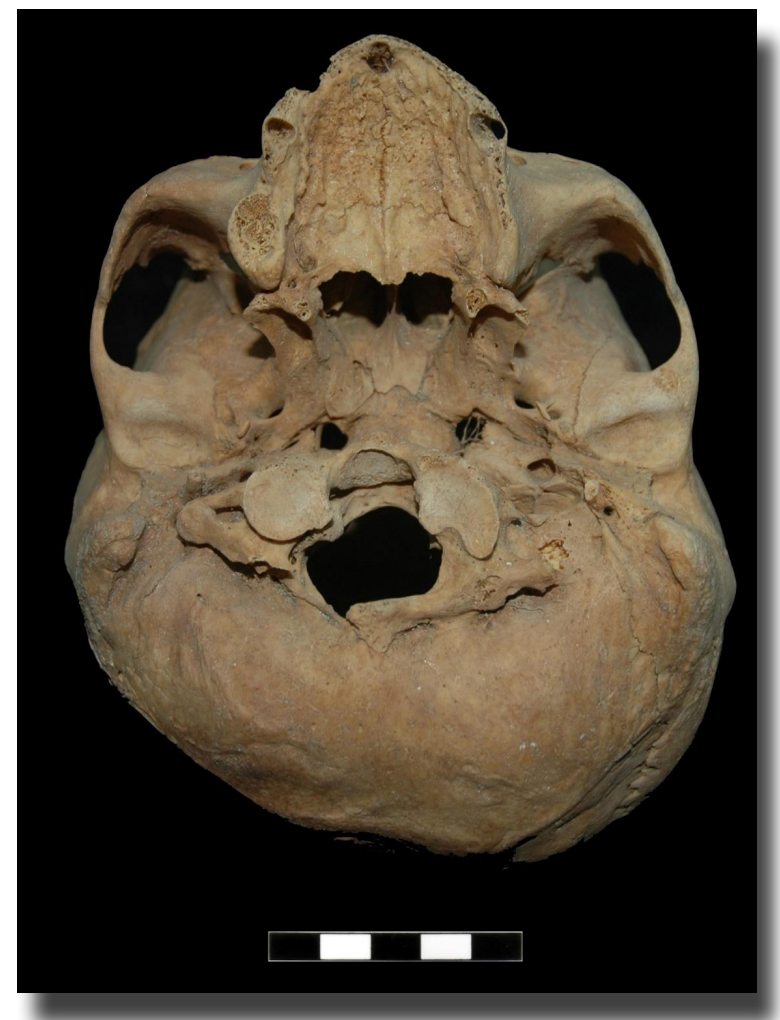

Resim 12. DK'90 CCE 24 numaralı kadın bireye (5660 yaş) ait kafatasında görülen "atlas occipitalizasyonu"

periostit gözlemlenmiştir. Bu bireylerden ikisi erkek biri kadındır. Periostit yalnızca tibialarda ve femurlarda gözlemlenmiştir. Dilkaya toplumunda periostit \%2,44 oranı ile en fazla erkek bireylerde gözlemlenmiştir. Cinsiyetler ve yaş grupları arasındaki farklılık istatiksel olarak anlamsizdır ( $<<0,1=\mathbf{6 , 2 5}, \chi^{2}: 3,66$, sd: 3 ) (Tablo $2,3)$.

\section{Dolaşım Sistemi Hastalıkları}

Dolaşım sistemi, vücudun yaşamsal faaliyetlerini sürdürmekle görevli en önemli sistemlerden biridir ve vücut hücrelerine, besin, oksijen ve hormon temininden sorumludur. Dolaşım sisteminde meydana gelebilecek en ufak aksaklık bireyin yaşamının sonlamasıyla son bulabilir (Ortner, 2003). Dilkaya toplumunda dolaşım sistemi hastalıklarından sadece Legg-Calve-Perthes anomalisine rastlanmıştır.

\section{a) Legg-Calve-Perthes}

Anomaliye sadece bir erkek bireyde rastlanmıştır ve bu birey 52-55 yaşlarındadır. Bireyin sol femurunun boyun kısmı sağ femuruna göre daha kısadır. Ayrıca sol femurun çaput kısmı sağ femura göre daha küçüktür. Sol coxanın acetabulum kısmı sağ coxaya göre daha sığdır. Bireyin sağ coxasında ve sağ femurunda herhangi bir patolojiye rastlanmamışır (Resim 13). Bireyin sol femurunda 3. derece osteoartrite rastlanmıştır (Tablo 2, 3).

\section{Retiküloendotelyal Sistem Hastalıkları}

Vücutta birbirinden çok uzak bölgelerde yer alan ve vücudun savunma mekanizmasını oluşturan hücre ve dokuların oluşturduğu sisteme retiküloendotelyal sistem adı verilir. Retiküloendotelyal sistem hücreleri, bakteri, virüs gibi mikroorganizmalar ya da kusurlu vücut hücrelerini sarıp yok ederek (fugositoz) vücudu hastalıklara karşı korurlar. $\mathrm{Bu}$ hücrelerin yapısı bozulduğunda lösemi, myeloma gibi hastalıklar ortaya çıar (Ortner, 2003).

\section{a) Multiple Myeloma}

Toplumda multiple myeloma olgusu yalnızca 65 yaş üzeri bir erkek bireyde gözlemlenmiştir (Resim 14). Yapılan gözlemler sonucunda bireyin kafatasının endocranial yüzeyinde, sağ ve sol claviculasinda, costalarında ve torakal omurlarda multiple myeloma kaynaklı lezyonlar gözlemlenirken, claviculalarda ise şekil bozukluklarına rastlanılmıştır. Erkek bireylerde multiple myeloma oranı $\% 1,21$ 'dir. Toplumun genelinde ise bu oran $\% 0,38$ olarak hesaplanmıştır (Tablo 2, 3).

\section{Tartışma}

\section{Yaşam Biçimine Bağlı Gerçekleşen Anomaliler}

Geçmişte yaşamış insan topluluklarını yaşam biçimlerini ortaya çıarma açısından en iyi ipuçlarını, yaşam boyu iskelet yapilarında meydana gelen değişimler verir. Dilkaya toplumunda yaşam biçimine bağlı anomaliler dokuz ana başlık altında incelenmiştir.

Toplumların yaşam biçimlerinin ve sağlik yapılarının anlaşılmasında kullanılan en önemli iskelet elementlerinden biri de omurgadır. Omurganın iki başlica görevi vardır: Vücuda destek olmak ve vücudun hareketini sağlamak. Omurların bazı bölümleri hareketi sağlarken bazı bölümleri vücuda destek olur. Omurlarda bu nedenle iki tip eklem bulunur: Intervertebral ve apofizyal eklemler. Fazla hareketli olmayan intervertebral eklemler vücuda destek eylemini yerine getirirler. Apofizyal eklemler ise hareketi sağlar (Knüsel vd., 1997). Ağırlık taşıma görevini yerine getiren intervertebral eklemlerin yer aldığ1 omurlarda, yaşam boyunca yıpranma ve osteofit görülme oranı, servikal omurlardan, lumbar omurlara gidildikçe artar. Lumbar omurlar gövdeden gelen tüm yükü kalça kemeri ve bacaklara ilettiklerinden yaşam boyunca en fazla yıpranan omur bölgesi lumbar omurlardır (Resnick ve Niwayama, 1988).

Apofizyal eklemlerde görülen osteoartrit ise genelde servikal omurlarda ve torakal omurlarda daha fazla görülür. $\mathrm{Bu}$ durumun sebebi üst ekstremitelerin hareketinden sorumlu olan trapezius ve rhomboid 


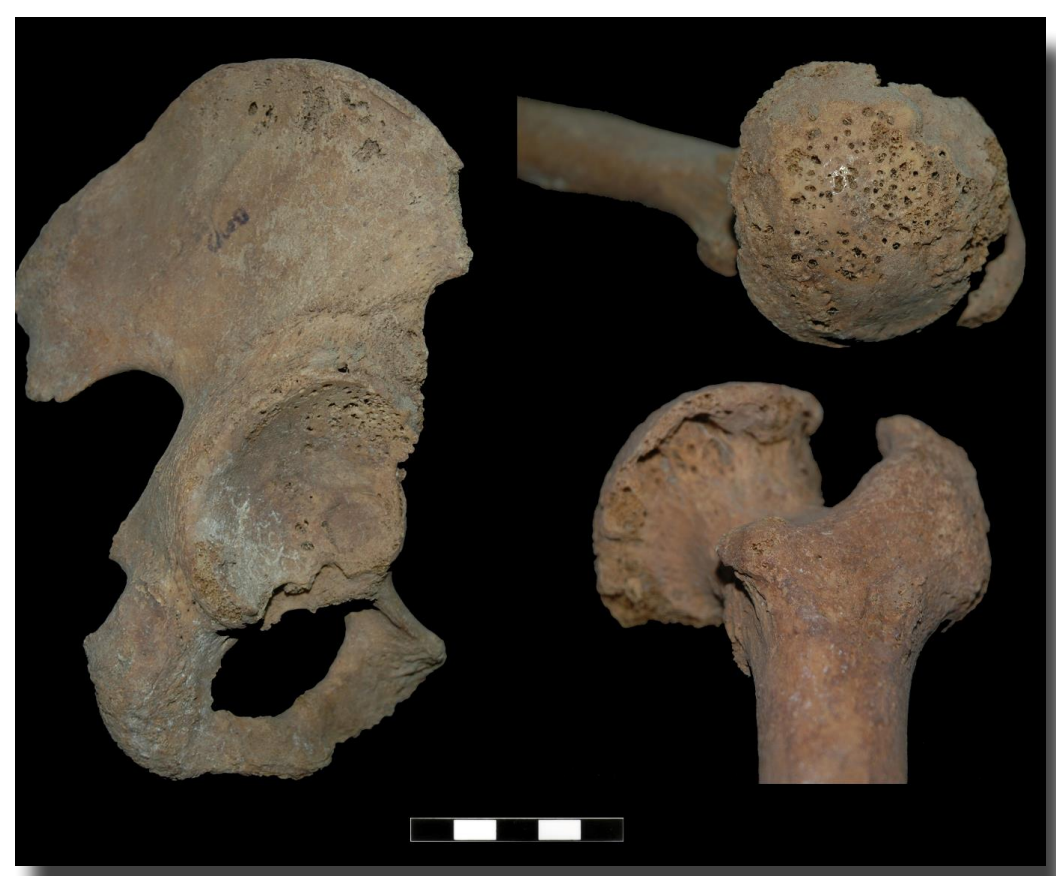

Resim 13. DK'88 BMD 48 numaralı erkek bireyde (52-55 yaş) Legg-Calve-Perthes

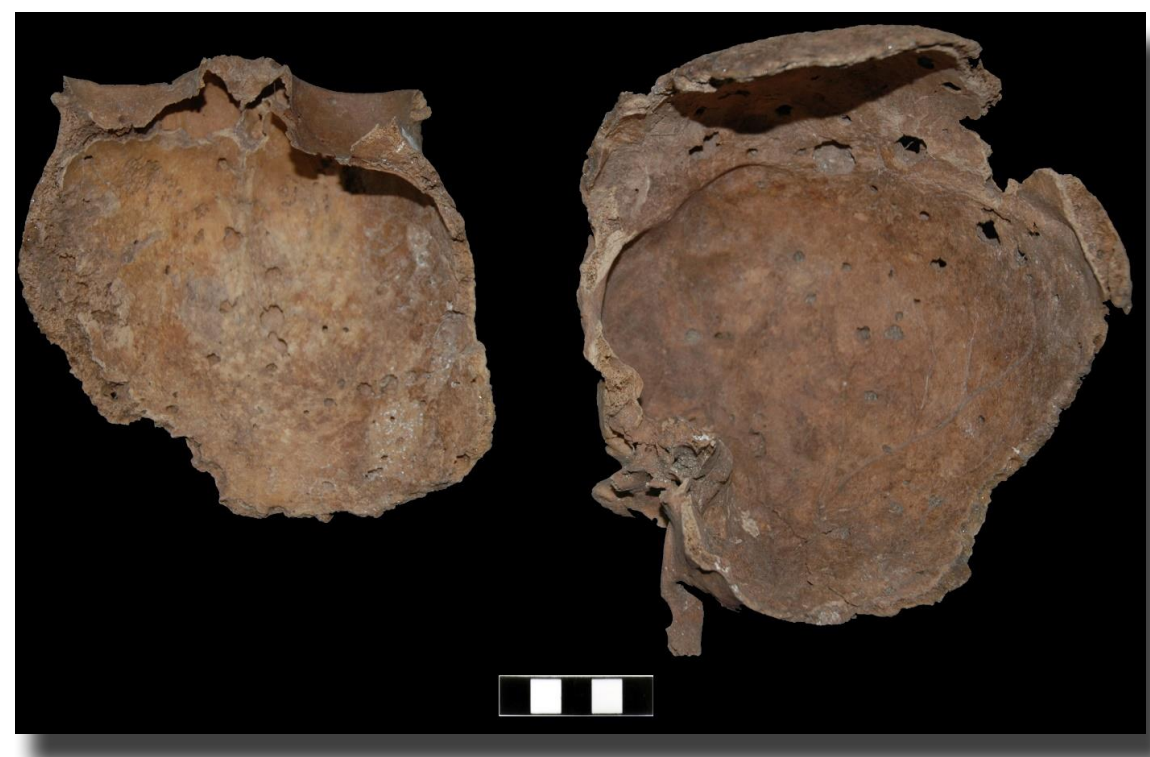

Resim 14. DK’90 CCT 38 numaralı erkek bireyde (67 yaş) kafatasının endocranial kısmında "multiple myeloma"

kaslarının servikal ve torakal omurlara tutunmasıdır. Omzun yukarı kaldırılıp aşağı çekilmesi, scapulanın hareketleri ve başın ters yöne döndürülmesinden bu kaslar sorumludur (Ellis, 2006).

Günümüzde yaşayan insanlara göre daha aktif ve hareketli bir yaşam tarzına sahip olan geçmiş toplumlarda vertebral osteoartrit, günümüz insanlarına kıyasla daha genç yaşlarda ortaya çıkar. Benzer şekilde kırsal alanlarda yaşayan çiftçilerle, modern kentlerde yaşayan ofis çalışanlarının eklemlerinde osteoartrit frekansı önemli bir farklılık sergileyebilir (Roberts ve Manchester, 2007). Kafa üzerinde yük taşımak boyun omurlarını, sırtta yük taşımak bel ve sırt omurlarını daha çok etkiler. Dolayısıyla avlarını sırtlarında taşıyan avcı- toplayıcılar ile ürünlerini sepet gibi araçlarla kafalarının üzerinde taşıyan tarımcılarda lezyonların frekansları farklilik sergiler (Roberts ve Manchester, 2007). Omurga osteoartritinin ağırlıklı olarak mesleğe dayalı olarak ortaya çıktığını destekleyen araştırmalardan biri 5000-4000 yıl öncesine tarihlendirilen antik İndüs medeniyetine ait Harappa iskelet serisinden elde edilmiştir (Lovell, 1994). Toplum genelinde, omur gövdelerindeki osteofitin oranı \%34'tür. Omur gövdelerinin yanı sıra, apofizyal eklem yüzeylerindeki ileri derecedeki lezyonlar, yine boyun omurlarında daha yüksek frekansa sahiptir. Lovell, kendi verilerini arkeolojik verilerle birlikte değerlendirmiş ve Harappa toplumunun kafa üzerinde yük taşıma alışkanlığında olduğu sonucuna ulaşmıştır (Lovell, 1994). 
Angel, Karataş Erken Tunç Toplumunda omurga eklem hastalığı oranını \%62 olarak belirlemiştir. Araştırmacı bu durumu ağır fiziksel stres ile ilişkilendirmiştir (Angel ve Bisel, 1986).

Dilkaya toplumunda vertebral osteofite en fazla lumbar omurlarda, en az ise servikal omurlarda rastlanmıştır. Vertebral osteofit erkeklerde çok daha fazla görülmüş ve görülme sıklığ1 yaşla beraber artış göstermiştir. Apofizyal osteoartrite ise en fazla servikal omurlarda rastlanılmıştır. Apofizyal osteoartrit de erkeklerde çok daha fazla görülmüss ve yaşla beraber artış göstermiştir. Toplumda erişkin bireylerin \%82,05'inin omurlarında osteoartrit gözlemlenmiştir. Toplumda vertebral osteoartrit oranın bu kadar yüksek olmasinın ana nedenlerinden biri Dilkaya bireylerinin ömür uzunluklarının diğer Anadolu toplumlarına göre görece yüksek olmasıdır. Diğer yandan günlük aktiviteler ve vertebral osteoartritit arasındaki ilişkiyi anlayabilmek amaciyla Van Gölü çevresi 16-17. Yüzyıl Osmanlı tarihi kayıtları incelenmiş ve önemli sonuçlara ulaşılmıştır. Bölge potansiyel olarak tarımsal faaliyetlere ve hayvancilığa uygun olmasina rağmen, yaşanan siyasi istikrarsızlıklardan dolayı, tarım ve hayvancilık faaliyetleri kısıtlıdır. Kayıtlara göre Van Gölü çevresinde buğday, arpa ve darı gibi hububatların yanı sıra yonca üretimi de yapilmıştır. Ayrıca bağcılık, bahçecilik ve bostancılık bölgede yapılan diğer tarımsal faaliyetlerdir. Bunların yanı sıra bölgedeki bir diğer geçim faaliyeti de hayvancilıktır. Bölgede küçükbaş hayvan yetiştiriciliği ve görece az olmakla birlikte arıc1lık yapıldığına ilişkin vergi kayıtları mevcuttur. Ayrıca çok az da olsa balıkçılık faaliyetleri sürdürülmektedir (Kılıç, 1997). Bu bilgiler Dilkaya Toplumu'nun günlük yaşamı hakkında ipuçları vermektedir. Bireylerin omurlarında gözlemlenen osteoartrit omurgayı etkileyen sürekli bir fizyolojik stresin göstergesidir. Servikal ve lumbar omurların yaygın şekilde dejenere olması, bu insanların geçim faaliyetlerinin tarıma dayalı olduğunu işaret etmektedir. Vertebral osteoartritin erkeklerde kadınlara göre daha yaygın gözlemlenmesi, toplumsal cinsiyet rolleri açısından erkeklerin fiziksel güce dayalı ağır işleri üstlendiğini, bununla birlikte kadınların da günlük yaşamda aktif olarak çalıştıklarını göstermektedir. Apofizyal osteoartritin servikal omurlarda daha fazla görülmesinin sebebi kolların günlük işlerde çokkullanımı ve kafa üzerinde yük taşıma alışkanlığı olabilir.

Aktivite ve osteoartrit ilişkisini analiz eden en önemli çalışmalardan biri Merbs tarafindan, soyu 1900'lü yılların başında tükenen Kanadalı bir Eskimo (Sadlermiut) grubuna ait iskeletler üzerinde yapılmıştır. Araştırmac1, Sadlermiut iskeletlerinde osteoartritin erkeklerde alt üyelerde, kadınlarda temporamandibular eklemde daha yaygin olduğunu tespit etmiştir. Omurga lezyonları kadınlarda sırt bölgesinde, erkeklerde ise bel bölgesinde yoğunlaşmıştır. Merbs, erkeklerdeki osteoartritin sebebi olarak zıpkın firlatma, kano çekme, ağır yük kaldırma ve taşıma aktivitelerini; kadınlarda ise kıyafet yapımı (ağızda deri işleme), çocukların sırtta taşınması ve kızak çekilmesi aktiviteleri olarak göstermiştir (Merbs, 1983). Eski Anadolu toplumlarında eklem hastalıklarına ilişkin çalışmalardan biri ise Angel tarafından Çatalhöyük iskeletlerinde yapılmıştır. Angel, Çatalhöyük neolitik toplumunda periferal eklem hastalığ1 oranını $\% 47$ olarak belirlemiştir. Çatalhöyük'te temporomandibular artrit \%26, occipital (kondilar) artrit \%60 oranındadır. Araştırmacı bu durumu ağır fiziksel stres ile ilişkilendirmiştir (Angel, 1971). Erdal tarafindan yapılan çalışmada, Neolitik-Yakın Çağ arasına tarihlenen 14 farklı topluma ait 622 erişkin iskeleti incelenmiştir. Araştırmacı, Neolitik'ten Demir Çağı'na doğru hastalığın frekansında azalma, Demir Çağı'ndan sonra tekrar yükselme eğilimi tespit etmiştir. Yaş ilerledikçe hastalığın frekansı artış göstermekte, 45 yaş üstü bireylerde $\% 96,3$ gibi yüksek bir orana ulaşmaktadır. Erdal, eski Anadolu toplumlarındaki eklem hastalığı frekansındaki farklılıklarını yaşam biçimine bağlamıştır (Erdal, 2004). Günümüz toplumları üzerinde yapılan çalışmalarda, tarım ile uğraşan çiftçiler ve havalı matkap gibi yüksek efor gerektiren işlerde çalışan insanlarda, mesleki strese bağlı osteoartrit gelişimi kaydedilmiştir (Jurmain, 1991). Jurmain'e göre periferal osteoartritin ortaya çıkmasında, genetik yapı düşünüldüğünden daha önemlidir (Jurmain, 1977).

Dilkaya toplumu, periferal osteoartrit açısından diğer Anadolu toplumlarıla karşılaştırıldığında (Grafik 1) oranın diğer toplumlarınkine yakın olduğu gözlemlenebilir. Toplumda periferal osteoartrit kadınlara kıyasla erkeklerde çok daha yaygin görülmekte ve yaşla beraber artış göstermektedir. Bu bulgu osteoartrit ile yaş arasındaki güçlü ilişkiye uygun düşmektedir. Periferal osteoartritin en çok etkilediği bölge dirsek eklemidir ve iki cinsiyet arasındaki farklılık istatistiksel açıdan anlamlıdır. Dirsek eklemini sırasıyla omuz ve kalça eklemleri izlemektedir. Tipk1 vertebral osteoartrit gibi periferal osteoartrit de özellikle erkeklerin kollarını ve vücudun üst kısmını günlük aktivitelerde yoğun olarak kullandıklarını işaret etmektedir.

Omurlar arasında onları birbirlerine bağlayan ve görevleri fiziksel stres ve travmaların etkilerini azaltarak omurga sistemine dengeli bir şekilde dağıtmak olan diskler (intervertebral disk) bulunmaktadır. Bu diskler bazı travmalar ya da patolojik olgular sonucunda hasar 


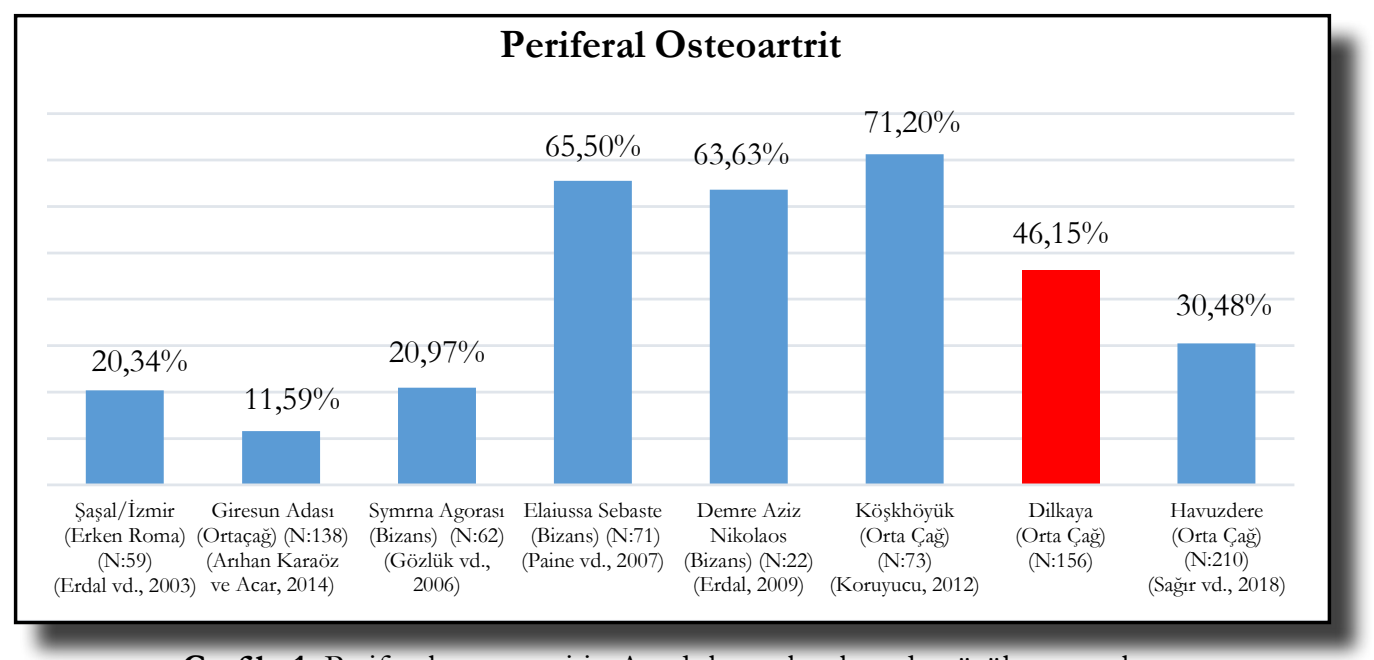

Grafik 1. Periferal osteoartritin Anadolu toplumlarında görülme oranları

görürler ve bazen normal pozisyonlarını kaybederler. $\mathrm{Bu}$ dokuların posterior veya inferior yönde pozisyonlarını kaybetmeleri sonucunda fitıklaşma oluşur (Aufderheide ve Rodriguez-Martin, 2006; Mann ve Hunt, 2012). Schmorl nodülleri yaşa bağlı olarak artış gösterirler. Ortaya çıkmalarında yüksekten düşme, ağır kaldırma, fiziksel aktiviteler esnasında oluşan travmalar gibi olgular etkendir (Mann ve Hunt, 2012). Ukrayna'da ele geçen iskeletler üzerinde Wentz ve De Grummond tarafindan yapılan çalışmada, bireylerin eklem bölgelerinde osteoartrite ve özellikle lumbar omurlarında schmorl nodülüne rastlanmıştır. Araştırmacılar bireylerin eklemlerinde gözlemlenen osteoartiriti ve omurlardaki schmorl nodülünü, at üstünde geçen bir yaşam biçiminin oluşturduğu fiziksel stresle ilişkilendirmişlerdir (Wentz ve De Grummond, 2009). Blau tarafindan Umman yarımadasından ele geçen ve M.Ö 5. yüzyılın sonlarına tarihlendirilen 400 birey üzerinde yapılan çalışmada omurlarda schmorl nodülleri gözlemlenmiştir. Blau, schmorl nodüllerinin ortaya çıkış sebebini bireylerin yüksek aktivite gerektiren işlerde çalışması ve görece olarak uzun bir hayat sürmesi olarak belirlemiştir (Blau, 2001).

Dilkaya toplumunda erişkin bireylerin \%89,74’ünün omurlanında schmorl nodülü gözlemlenmiştir. Schmorl nodülüne en fazla lumbar omurlarda, en az ise servikal omurlarda rastlanılmıştır. Schmorl nodülü erkeklerde çok daha fazla görülmüş ve yaşla beraber artış göstermiştir. Görülme oranının yüksek olması ve erkeklerde daha fazla görülmesinin nedeni olasılıkla yüksek efor gerektiren işlerin omurgayı yaşam boyu tahrip etmesidir.

Dilkaya toplumunda incelenen bireylerde ankylozan spondilitis ve DISH de gözlemlenmiştir. Kadın bireylerde ankilozan spondilitis görülme oran1 \%1,61, erkek bireylerde \%3,51'dir; toplumun genelinde ise $\% 1,95$ 'tir. Toplumda sadece bir erkek bireyde DISH'e rastlanmıştır $(\% 0,84)$.
Dilkaya toplumunda bazı bireylerde ankilozan spondilitise rastlanmasının muhtemel sebebi yaşam boyu yüksek efor gerektiren çalışma koşullarının ortaya çıkardığ1 strestir. DISH, yüksek tansiyon, şeker hastalığ1, kalp hastalığ1 ve obezite ile birlikte ve 50-60 yaşlar arasindaki erkeklerde daha sık görülür (Ortner, 2003; Aufderheide ve Rodriguez-Martin, 2006). Toplumda DISH sadece 50 yaş üzeri bir erkekte gözlemlenmiştir. Bireyin cinsiyeti ve yaşının hastalığın etiyolojisine uygun olmas1, söz konusu bireyin DISH’in ortaya çıkmasına sebep olan rahatsılıklardan en az birine sahip olduğunu düşündürmektedir.

DFCE, gastrocnemius kasının tekrarlanan çekmegerilme hareketi nedeniyle zarar görmesi veya lokalize kemik erimesi gibi travmatik bir olay sonucunda ortaya çıkar. Toplumda özellikle erkeklerde DFCEgörülmesinin sebebi muhtemelen yaşam boyu sürdürülen günlük issler sirasında yürüme, ayakta durma, diz bükme gibi hareketlerin sürekli tekrarlanmasından kaynaklanan travmalardır. DFCE'na rastlanan bireylerin neredeyse tamaminda entosopati meydana geldiği de belirlenmiştir. Entesopati, tendonlar ve ligamentlerin kemiklere temas ettikleri bölgelerde, kas veya tendonlarda iltihaplanma, yaşl1lık, şişmanlık, belirli bir faaliyetle ilgili tekrarlanan hareket veya akut stres nedeniyle ortaya çıkar ve calcaneusla achilles tendonun bağlantı yaptığı; patella ile quadriceps femoris tendonunun birleştiği ve tibianın popliteal kasla bağlantı yaptığ1 bölgelerde görülür. Dilkaya Toplumunda erisskin bireylerde entosopati görülme oran1 \%25,64’tür. Entesopati en fazla tibialarda ve calcaneuslarda gözlemlenmiştir. Dilkaya örneğinde entesopatilerin en fazla yaşlı erkek bireylerde ve özellikle alt bacak kemiklerinde gözlemlenmesi, bu lezyonun günlük işler ve tarımsal faaliyetler sırasında sürekli tekrarlanan bacak hareketleri sonucunda oluştuğunu düşündürmektedir. DFCE ve entesopatilerdeki cinsiyet farklılığ1, aynı zamanda Dilkaya toplumunun günlük 
hayatın kadın ve erkekler arasındaki iş bölümüne ilişkin ipuçları sağlar.

Entosopatilerin günlük yaşamla ilişkisi farklı araştırmacılar tarafindan tartışılmıştır. Örneğin Larsen, Kuzey Amerika yerlilerinin iskeletleri üzerinde yaptığ1 çalışmada tespit ettiği entosopatilerin at biniciliğine bağlı olduğunu aktarmıştır (Larsen, 1997). Digangi ve diğerleri tarafından Amerika Birleşik Devletleri'nin Mississippi eyaletinde bulunan ve M.S. 900-1600 y1lları arasına tarihlendirilen iskeletler üzerinde yapılan çalışmada bir bireyin femurlarından birinde kısalık ve tibialarının proximal kısminda entosopatilere rastlanmıştır. Digangi'ye göre bu birey hayatı boyunca topallayarak yürümüş ve bu durum bireyin quadriceps kaslarına baskı yapmıştır. Bunun sonucunda da bireyin tibialarında entosopati meydana gelmiştir (Digangi vd., 2010).

İskelet ve kas sistemini etkileyen stresin göstergelerinden biri de rhomboid fossadır. Daha çok erkeklerde görülen bu anomalinin sebebi göğüs bölgesine etki eden çalışmalarda sıklıkla bulunmak ve güç gerektiren eylemlerde dominant kolun fazla kullanımıdır (Taylor ve Resnick, 2010; Mann ve Hunt, 2012). Sirtta yük taşıma da bu lezyonun ortaya çıkmasında etkilidir (Molleson ve Hodgson, 2003). Dilkaya toplumunda kadın bireylerde rhomboid fossa görülme oranı $\% 12,06$, erkek bireylerde ise $\% 23,73^{\prime}$ tür. Toplumun genelinde ise bu oran \%12,80'dir. Dilkaya toplumunda rhomboid fossa en fazla erişkin erkek bireylerde gözlemlenmekle birlikle cinsiyetler arasinda anlamlı bir fark yoktur ve olgunun görülme sıklığ1 yaşla birlikte artmaktadır. İskelet kas sitemini etkileyen diğer stres faktörleri gibi bu lezyon da günlük aktivitelere ilişkin bilgiler vermektedir. Toplumda rhomboid fossanın görülme nedeni bireylerin yaşamları boyunca devam eden ve vücudun üst kısmını zorlayan faaliyetler sirasinda costoclavicular ligamentlerin yoğun bir biçimde kullanılmış olmasıdır.

Spondylolysis genetik kaynaklı bir anomali olarak düşünülse de anomalinin ortaya çıkmasında stresin, aşırı çalışma gibi faktörlerin baş rolde olduğu düşünülmektedir. Son y1llarda atletler, jimnastikçiler ve Amerikan futbolu oynayan bireyler üzerinde yapılan araştırmalara göre yüksek aktivite ve omurga üzerine yapılan aşırı baskılar bu anomalinin görülmesine neden olmaktadır (Aufderheide ve Rodriguez-Martin, 2006; Mann ve Hunt, 2012). Henüz omurları tam olarak kaynaşmamış genç bireylerin yaşamlarının erken dönemlerinde intervertebral disklerine zarar veren aktivitelerde bulunması bu anomalinin temel sebeplerinden biridir. Lessa, Brezilyalı balıkçıklar üzerinde yaptığı çalışmalarda omurganın lumbar kısmını zorlayan zıpkın firlatma, ağ atma, kürek çekme gibi faaliyetlerin bu anomaliye neden olduğunu ve spondylosisin erkeklerde daha çok görüldüğünü rapor etmiştir (Lessa, 2011).

Toplumda spondylolysis en fazla kadinlarda gözlemlenmiştir. Ancak cinsiyetler arasındaki farklılık istatistiksel olarak anlamsızdır. Bunun nedeni genç bireylerin yaşamlarının erken dönemlerinde kız erkek ayrımı olmadan beraberce yüksek aktivite gerektiren işlerde çalışması olabilir.

Dilkaya ile diğer Anadolu toplumları karşılaştırıldığında, toplumda travmaya oldukça az rastlandığ1 görülmektedir (Grafik 2). İncelenen diğer Anadolu toplumlarinda birey sayısının az olmasi yanıltıc1 olabilir. Dilkaya Toplumunda kafatası travmalarının büyük bir çoğunluğu, gövde travmalarının ise tamamı erişkin erkeklerde gözlemlenmiştir. Harappa'da (Pakistan) yapılan çalışmada travmalar yüksek oranlarda

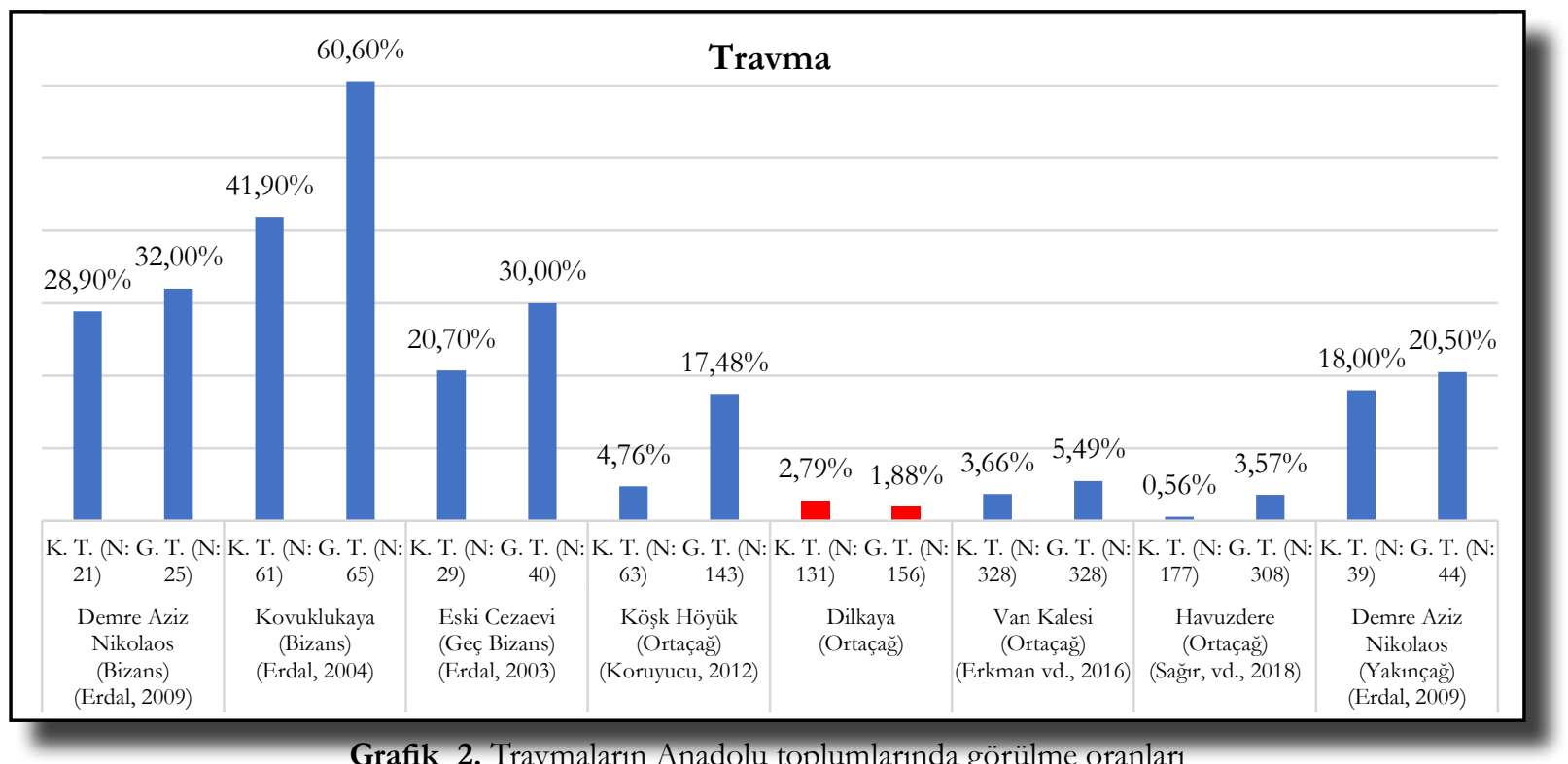

Grafik 2. Travmaların Anadolu toplumlarında görülme oranları

(K.T.: fafatası travmas1, G.T.: gövde travmas1, N: incelenen birey sayıs1) 
görülmese de özellikle sosyal açıdan daha düşük bireylerin gömüldüğü mezarlardan elde edilen kafataslarında, travmalara daha fazla rastlanmasi nedeniyle bu durumun sosyal farklilıklarla ilgili olduğu sonucuna varılmıştır (Schug vd., 2012). Dilkaya toplumunda ise mezarlar arasında sosyal statü fark1 yoktur ve gözlemlenen travmalar muhtemelen düşme, çarpma gibi çalışma koşullarının ortaya çıkarttığı küçük kazalar sonucunda meydana gelmiştir ve gövde travmalarının tamamı bireyin yaşamı esnasında iyileşmiştir.

\section{Metabolik Hastalıklar}

Cribra orbitalia ve porotic hyperostosis lezyonlar1 eski insan topluluklarında aneminin göstergeleri olarak değerlendirilmektedir. Birçok nedene bağlı olarak ortaya çıkabilse de, anemilerin görülme nedenleri genel olarak kalıtsal anemiler ve edinsel anemiler olarak ikiye ayrilır. Kalitsal olarak siniflandırilan anemilerde bireylerde cribra orbitalia ve porotic hyperostosis lezyonlarının yanında uzun kemiklerde kemik dokusu kaybı, şekil bozuklukları, kemiklerin kortikal dokularında azalma, yüz kemiklerinde genişleme gibi değişimler de izlendiği belirtilmektedir (Roberts ve Manchester, 1995; Ortner, 2003; Büyükkarakaya ve Erdal, 2012). Edinsel anemilerin önemli nedenleri demir emiliminde ortaya çıan bozukluklar ve B12 vitamini ile B9 (folik asit) vitamini eksikliğidir. Bu vitaminlerin yeteri kadar alınamaması sonucunda kırmızı kan hücrelerinin üretimi sekteye uğrar ve bu durum megaloblastik anemiye neden olabilir. Vücudun demiri yeteri kadar alamamas1 ise demir eksikliği anemisine yol açabilir (Büyükkarakaya ve Erdal, 2012).

Alyuvarlar yaşamın erken dönemlerinde, dalak ve karaciğgerde üretilirken, çocukluktan itibaren uzun kemiklerin ilik boşlukları ile kafatasının diploe kısmında üretilmektedir. Erken çocukluk döneminde ise hızlı büyüme süreci nedeniyle bireyin demire olan ihtiyacinı arttırmaktadır. $\mathrm{Bu}$ dönemde beslenme vasitasiyla demir eksik alınırsa bireyde demir eksikliğine bağlı anemi gözlemlenebilir. Bu durum bireyin bağış1klık mekanizması zayıflatır ve bu süreç bireyin yaşamının sonlanmasıyla sonuçlanabilir (Özbek, 2012). Düşük sosyoekonomik durumun getirdiği olumsuz yaşam koşulları, uzun süreli emzirme dönemi, enfeksiyonel hastalıkların yaygınlığ1, yoğun tarımsal faaliyetin bir sonucu olan ağırlıklı karbonhidrat tüketimi, sindirim sistemi parazitleri nedeniyle bağışıklık sisteminin zayıflamasının demir emilimini bozması gibi nedenler demir eksikliğinin ortaya çıkmasına neden olan koşullardır (Özbek, 2012).

Dilkaya toplumu cribra orbitalia görülme oranı açısından diğer Anadolu toplumlarıyla karşılaştırıldığında çağdaşı topluluklar arasında neredeyse en düşük değerleri veren toplumdur (Grafik 3). Toplumda rastlanan porotic hyperostosis oranları ise çağdaşları arasında en düşük değerlere sahiptir. Dilkaya toplumunda cribra orbitalia en fazla 4-10 yaş arasındaki bireylerde gözlemlenmiştir. Porotic hyperostosis lezyonu da en fazla çocuklarda görülmüştür ve bu bireylerde ayrıca diploe kalınlaşmasına rastlanmamıştır. Toplumda cribra orbitalia ve porotic hyperostosis lezyonları gözlemlenen bireylerde kalitsal anemiden kaynaklanan bulgular mevcut değildir. Bu nedenle Dilkaya'da gözlemlenen anemiye bağlı lezyonların demir eksikliği anemisinden kaynaklandığ1 düşünülmektedir. Dilkaya toplumunda demir eksikliği anemisinin göstergeleri olan cribra orbitalia ve porotic hyperostosise diğer toplumlara göre daha az karşılaşılması sosyo-ekonomik durumunun göreceli olarak iyi olduğunun bir göstergesi olabilir. Ancak Güleç ve diğerleri, Dilkaya toplumundaki çocukların büyümesinin, 3-4 yaşları civarı hariç, yaklassık 10 yaşına kadar karşılaştırma yapılan diğer Anadolu toplumlarindan daha geride olduğu sonucuna ulaşmışlardır (Güleç vd., 1993). Erkman, Dilkaya bebek ve çocuklarında büyüme döneminde meydana gelen büyüme duraklamasını hypoplasia bulgularına dayanarak tartışmıştır (Erkman, 2008). Dilkaya bebek ve çocuklarında ölüm oranı \%51'dir. Bu oran Anadolu orta çağ1 ortalamasının üzerindedir. Erişkinlere bakıldığında ise 46 yıllık yaşam uzunluğu Anadolu orta çağ toplumları üzerinde bir yaş ortalamasıdır (Güleç ve Özer, 2009). Bu durum doğurganlı̆̆ın yüksek olduğunun, bireylerin büyüme döneminde çeşitli sebeplerle yaşamlarını kaybettiklerinin, bu evreyi atlattıktan sonra ise göreceli olarak uzun bir hayat sürdüklerinin göstergesidir. Bu nedenle toplumda cribra orbitalia ve porotic hyperostosise diğer toplumlara göre daha az karşılaşılmasının muhtemel sebebi, çocuk ve bebeklerin anemi gibi hastalıklara yakalandıklarında hastalık henüz kemikte tahribata başlamadan, çok hızlı bir şekilde yaşamlarının sona ermesi olabilir.

Dilkaya toplumu diğer Anadolu toplumlarıyla D vitamini eksikliği görülme oranı açısından karşılaştırıldığında çağdaşı topluluklar arasında neredeyse en düşük değerlerle karşılaşılmıştır (Grafik 4). $\mathrm{D}$ vitamini eksikliği, yetersiz güneş 1şı̆̆ı alımı ve yetersiz beslenme sonucu ortaya çıkar. Ancak beslenme eksikliği ve yetersiz güneş 1şı̆̆ı alımının yanında geleneksel kapalı giyim tarzı, düşük sosyo-ekonomik düzey, kötü barınma koşulları, emzirme süresinin uzun olması gibi etmenler de D vitamini eksikliğine neden olabilir (Brickley ve Ives, 2008; Büyükkarakaya ve Erdal, 2009).

Van Gölü Havzası'nda yıllık sıcaklık ortalaması $9^{\circ} \mathrm{C}$ 'dir. Kışlar soğuk, yazlar sıcak geçer; kış mevsimi uzun sürer. Ekim ayında başlayan soğuklar, mayıs ayına kadar devam eder. Van Gölü sayesinde kışlar çok sert geçmemektedir ancak bölgede yllın ortalama 132 günü donlu geçer. Havalar ancak mayıs ayına girildiğinde 1sınmaya başlar. Yaz aylarında yılda ortalama 87 yaz gününe ve 19 tropik güne rastlanır (Kalelioğlu, 1991). Van Gölü Havzası'ndaki kötü hava şartlarına rağmen toplumda D vitamini eksikliğine bağlı hastalıklar diğer 


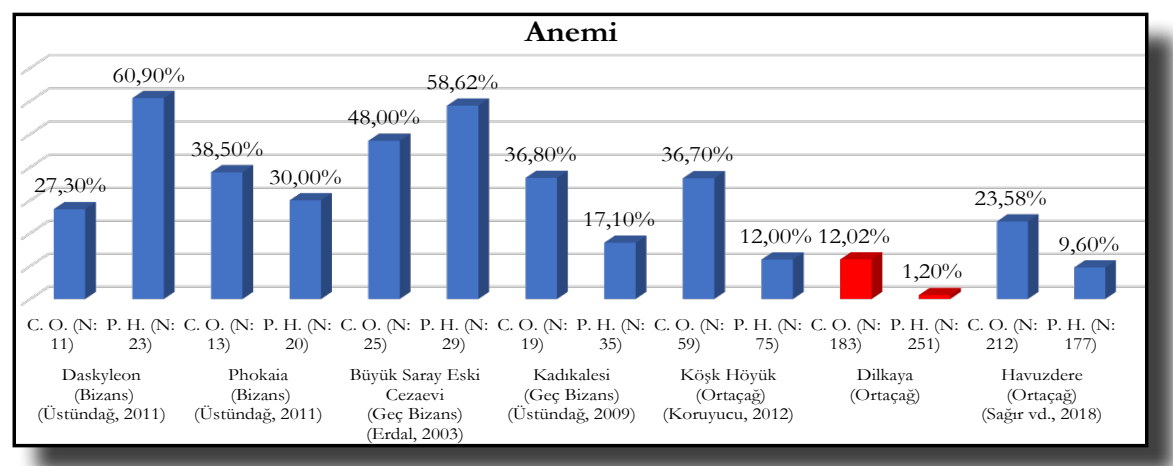

Grafik 3. Cribra orbitalia ve porotic hyperostosisin Anadolu toplumlarında görülme oranları (C.O.: cribra orbitalia, P.H.: porotic hyperostosis, $\mathrm{N}$ : incelenen birey say1s1)

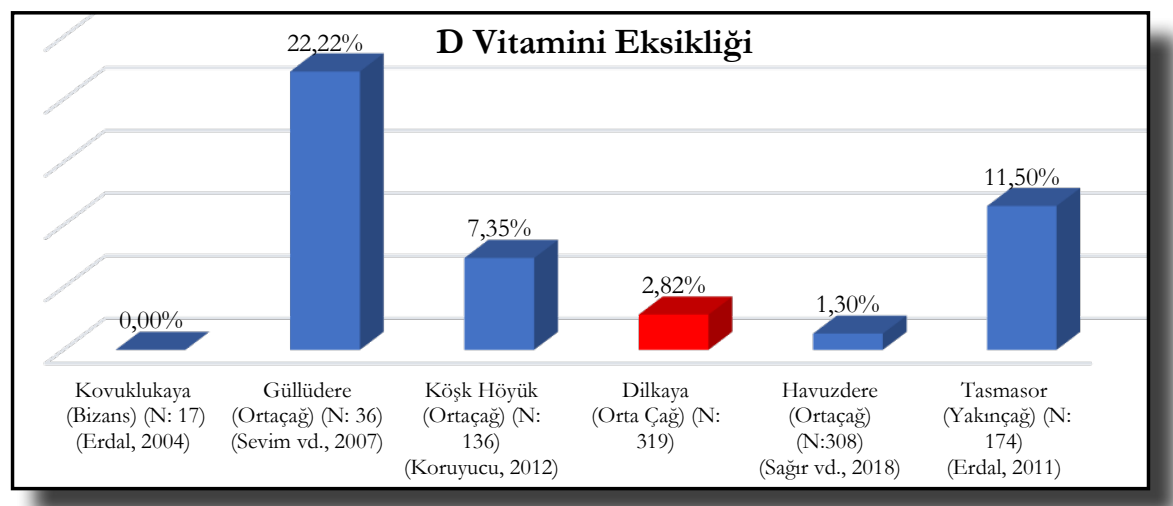

Grafik 4. D vitamini eksikliğinin Anadolu toplumlarında görülme oranları

toplumlara göre daha az görülmüştür. Erkman 2008 y1lında yaptığı çalışmada Dilkaya toplumunda ana besin öğesi olarak ekmeğin kullanıldığını ve tüketimde bunu yulaf lapası gibi tahıldan yapılmış yemeklerin izlediğini, bu toplumun zengin hayvansal gidalara ve yüksek kalorili beslenme alışkanlıklarına sahip olmadığını belirtmiştir (Erkman, 2008). Erkman, Dilkaya toplumunda tespit ettiği diş çürükleri ve diş kayıplarının muhtemelen undan yapılan ekmeğin yanı sıra tüketilen karbonhidratlı ve nişastalı yiyeceklerle bir bağlantısı olduğunu düşünmektedir (Erkman, 2008). Tüm bu veriler Dilkaya toplumunun diyetinin tarımsal gida ağırlıklı olduğunu gösterebilir. Toplumda D vitamini eksikliğine bağlı rahatsizliklara az rastlanmasinin muhtemel nedeni, toplumunun diyetinde tarımsal ürünlerin yanında yumurta ve süt ürünleri gibi hayvansal gidalar ile Van Gölü’nde yaşayan endemik bir tür olan inci kefali gibi D vitamini açısından zengin besinlerin de yer alması olabilir.

\section{Metabolik Hastalıklar}

Doğuştan anomaliler rahim içi yaşam boyunca, gelişim sürecinde ortaya çıkan patolojik değişimlerdir. $\mathrm{Bu}$ anomaliler doğum esnasinda veya sonrasinda gözlemlenebilir (Aufderheide ve Rodriguez-Martin, 2006). Dilkaya toplumunda yedi değişik konjenital anomaliye rastlanılmıştır.

Konjenital anomalilerden biri olan spina bifida genetik kökenli bir rahatsızlıktır. Ancak, fetusun gelişmesi esnasında folik asit (vitamin B12), çinko ve selenyumun yeteri kadar alınamaması nedeniyle ortaya çıktığı da düşünülmektedir (Roberts ve Manchester, 2007). Anadolu toplumlarinda spina bifida olgusu (Grafik 5) en fazla Minnetpınarı toplumunda gözlemlenmektedir. Ancak Minnetpinarı toplumunda çok az birey spina bifida açısından incelenebilmiştir (Özdemir ve Erol, 2010). Dilkaya'da spina bifida olgusunun gözlemlenme oranı diğer toplumlardan yüksektir. Dilkaya toplumunda gözlemlenen spina bifida anomalisinin muhtemel nedeni genetik kalitımdır.

Dilkaya toplumunda sakralizasyon en fazla erkek bireylerde gözlemlenmiştir ve yaşa bağlı olarak da artış göstermektedir. Ancak sakralizasyon anomalisinin ortaya çıkma nedeni bilinmemektedir ve muhtemelen genetik kökenli bir rahatsızlıktır. Araştırmacılar tarafından sakralizasyonla cinsiyet ve yaş arasında anlamlı bir korelasyon kurulamamıştır (Grafik 6).

Dilkaya toplumunda gözlemlenen diğer konjenital anomaliler sakral agenezi, çoklu blok omur, ayrık transvers ç1kıntı, yarık ark, atlas occipitalizasyonudur. $\mathrm{Bu}$ anomalilere iskelet toplumlarinda ender rastlanilir. $\mathrm{Bu}$ nedenle yukarıda bahsi geçen anomaliler Anadolu toplumlarıyla karşılaştırılamamıştır.

Konjenital anomaliler doğum esnasında veya sonrasında gözlemlenebilir. Kalıtsal olarak gelişebilir ya da döllenme ile doğum süreci arasında oluşabilirler. Endüstriyel toplumlarda gözlemlenen doğuştan 


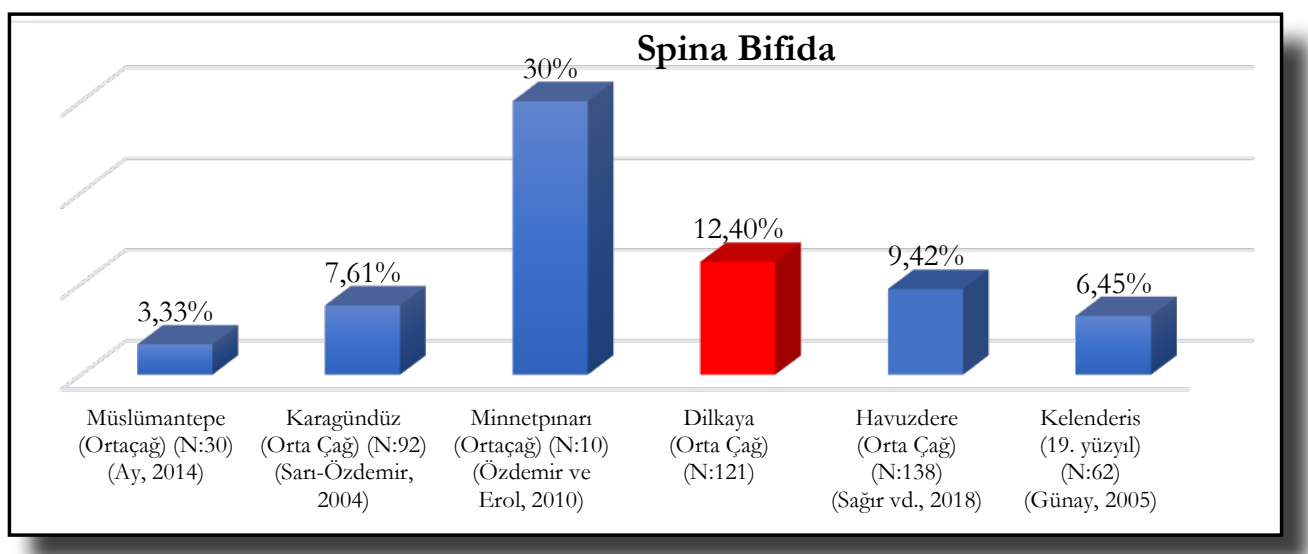

Grafik 5. Spina bifida ${ }^{1}$ anomalisinin Anadolu toplumlarında görülme oranları

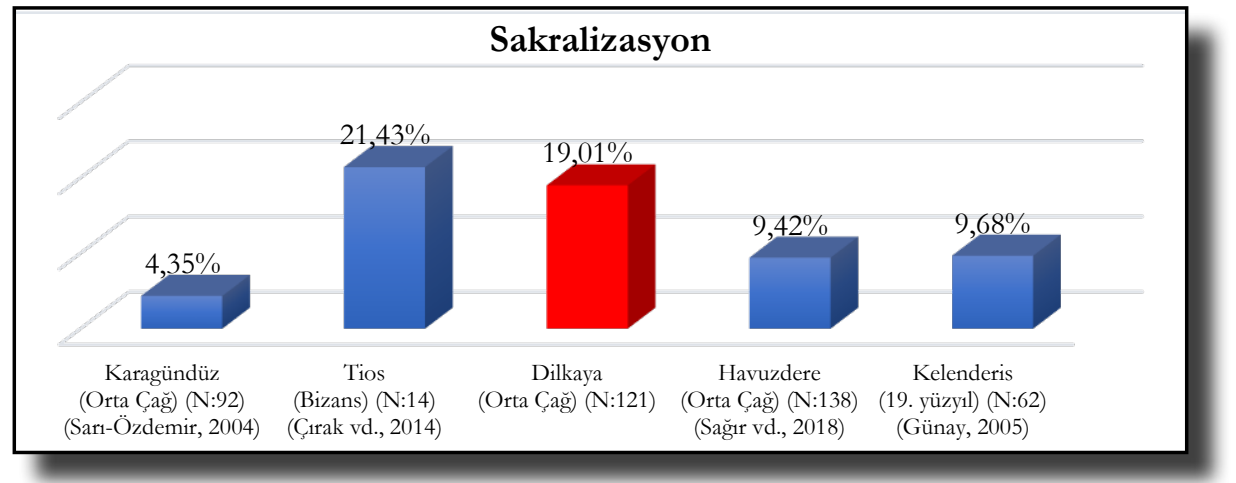

Grafik 6. Sakralizasyon anomalisinin Anadolu toplumlarında görülme oranları

anomalilerin \%90'ının genetik kökenli olduğu düşünülmektedir (Aufderheide ve Rodriguez-Martin, 2006). Lumbo sakral menengomyesel, spina bifida, omurga gelişim bozuklukları, en sık görülen genetik kökenli hastalıklardır. Soy içi evlilikler, ender görülen otozomal resesif hastalıkların görülme riskini önemli oranda artırmaktadır. Akraba evlilikleri, gelişmiş ülkelerde azalmasına karşın, gelişmekte olan ülkelerde yayg1ndır ve Türkiye'de her dört evlilikten birinin akraba evliliği olduğu ve çoğunlukla (\%70) kuzenler arasında gerçekleştiği saptanmıştır (Kutlubay, 2007). Altuntek'e göre, Doğu ve Güneydoğu Anadolu Bölgeleri’ndeki bazı etnik gruplarda soy içi evlilik tarihi ve kültürel boyutta süregelmektedir. Soy içi evliliğin başlica nedeni olarak yine bu bölgelerin soya dayalı ayrışmış (aşiret/kabile) yapısı gösterilebilir (Altuntek, 2001). Altuntek, Tunçbilek ve Ulusoy'un 1987 y1lında Türkiye genelinde yaptıkları araştırma sonuçlarına göre akraba evliliğinin batı Anadolu'da \%10,18 iken Doğu Anadolu'da \%32,86'ya çıktı̆̆ını aktarır (Altuntek, 2001). Ökten, Güneydoğu Anadolu Bölgesi'nde aşiret tipi toplumsal örgütlenmenin temelinin akraba evliliklerine dayandığını anlatır. GAP bölgesinde akraba evliliği oranını, \%47, Mardin'de \%54,9 ve Şanlıurfa'da \%54,7

\footnotetext{
${ }^{1}$ Dilkaya toplumunda spina bifida anomalisi üç faza ayrılarak incelenmiştir. Üçüncü faz, spina bifida anomalisinin tam olarak gözlemlenebilen halidir. Ancak birçok araştırmacı birinci fazı da spina bifida olarak değerlendirmektedir. Bu nedenle diğer toplumlarla karşılaştırma yapılırken ikinci ve üçüncü faz spina bifida gözlemlenen bireyler dikkate alınmıştır.
}

olarak vermiștir (Ökten, 2009). Daha yakın zamanda Malatya'da akraba evliliği ve konjenital anomaliler üzerine yapılan bir araştırmada akraba evliliğinin oranı \%28,4 olarak belirlenmiştir. Araştırma sonucunda, akraba evliliklerindeki genetik bozuklukların ve düşükle sonuçlanan hamileliklerin oranı, normal evliliklere göre istatistiksel açıdan önemli derecede yüksektir. Akraba evliliklerinde genetik bozuklukların oranı \%6,7-8,2 arasında değişirken, normal evliliklerde bu oran \%1,4'e düşmektedir (Yüksel vd., 2009). Bu çalışmalardan da anlaşılacağı gibi yakın akrabalar arasında yapılan soy içi evliliklerde konjenital anomalilerin ortaya çıkma olasılığı fazladır. Dilkaya toplumunda yedi değişik konjenital anomaliye rastlanılmıştır ve toplumda gözlemlenen konjenital anomalilerin tamamı genetik kökenli anomalilerdir. Toplumda frekansları düşük de olsa yedi farklı konjenital anomaliye rastlanması, bu anomalilerin nedeninin genetik kalıtım olduğu düşünüldüğünde Dilkaya toplumunda soy/aile içi evliliklerin yaygın olduğunu işaret etmektedir.

\section{Enfeksiyonel Hastalıklar}

Dilkaya toplumu diğer Anadolu toplumlariyla enfeksiyonel hastalıkların görülme oranı açısından karşılaştırıldığında çağdaşı topluluklar arasında en düşük değerlerden biriyle karşılaşılmıştır. Enfeksiyonel hastalıklar, bakteriler, virüsler, mantarlar, parazitler ve mikroorganizmalar yoluyla gelişir. Bir toplumda 


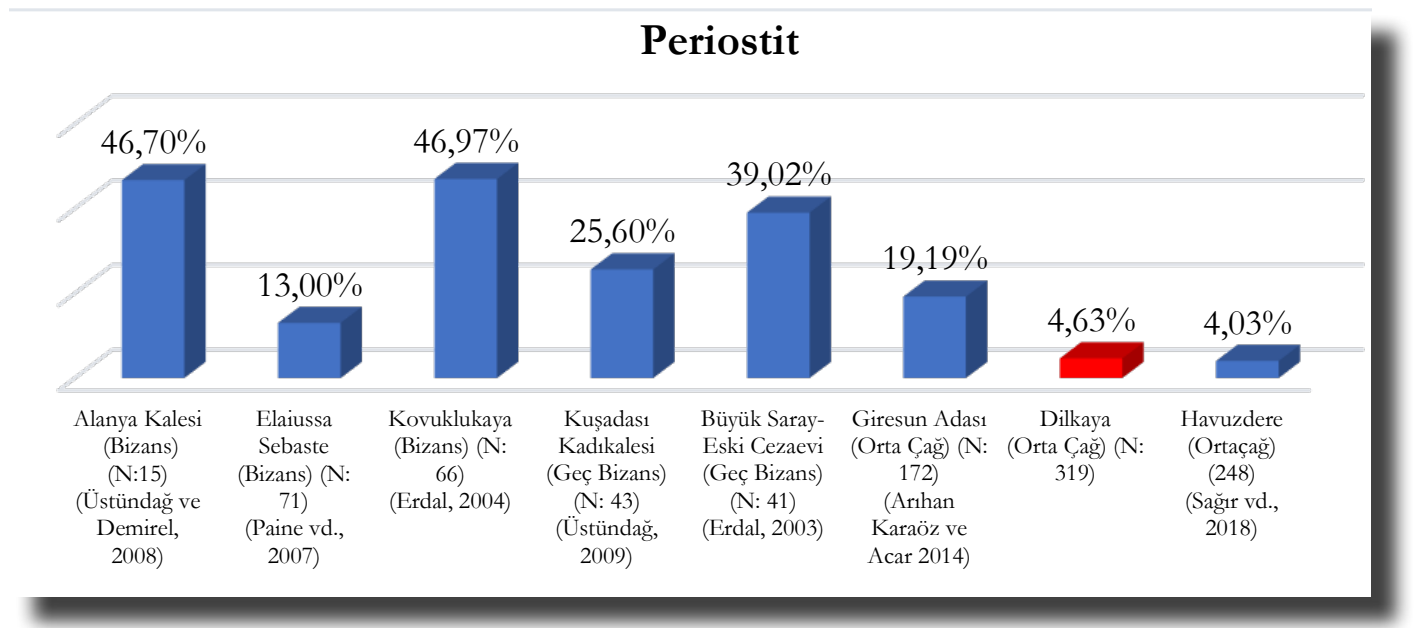

Grafik 7. Periostitin Anadolu toplumlarında görülme oranları

enfeksiyonel hastaliklara fazla rastlanmasinda toplumun yaşadığ1 çevrenin hijyen açısından yeteri kadar elverişli olmaması, nüfusun yoğun olması, sosyoekonomik faktörler ve travmalar önemli rol oynar (Ortner, 2003). Dilkaya Toplumu'na ait veriler diğer Anadolu toplumlarına benzemeyen farklı bir örüntü sergiler (Grafik 7). İlk olarak bebek ve çocuklarda periostit lezyonuna rastlanmamıstır ve bu lezyonun erişkinlerdeki oranı sadece \%4,63'tür. Üstelik kadın ve erkekler arasında anlamlı bir farklilık da yoktur. Oysa araştırılan diğer Anadolu toplumlarında bu lezyon ciddi oranlarda seyretmektedir. Dilkaya'nın ilginç bir diğer özelliği yukarıda tartışılan metabolik hastalıklardan anemiye ait lezyonların da çok düşük oranlarda meydana gelmesidir. İkisi bir arada değerlendirildiğinde iki sonuca ulaş1labilir; ya Dilkaya gerçekten yaşamak için çok uygun koşullara sahip bir yerleşimdir -ki \%51 bebek-çocuk ölümü durumun böyle olmadığının işaretlerini verir, ya da Dilkayalı bireyler enfeksiyonların kemikleri etkileyemeyeceği kadar hızlı bir şekilde hayatlarını kaybetmişlerdir.

\section{Dolaşım Sistemi Hastalıkları}

Dilkaya toplumunda bir dolaşım sistemi hastalığ olan Legg-Calve-Perthes'e sadece bir erkek bireyde rastlanmıştır $(\% 0,64)$. Legg-Calve-Perthes çocuklarda femurun gelişimi esnasında femur başı epifizinin kan dolaşımı yoluyla gerçekleşen beslenmesinin bozulmasıly ortaya çıkan bir hastalıktır. Hastalığın oluşum nedenleri tam olarak bilinmese de perthesli hastalarda protein $\mathrm{C}$ ve $S$ düzeylerinin daha düşük olması nedeniyle kalıtsal trombofilinin hastalığın meydana gelmesinde etkili olduğu düşünülmektedir (Aksoy vd., 2005; Aufderheide ve Rodriguez-Martin, 2006). Dilkaya toplumunda yalnızca bir erişkin erkekte Legg-Calve-Perthes'e rastlanmıştır. Bireyde bu hastalığın ortaya çıkmasının muhtemel nedeni çocukluk evresinde femurun gelişimi esnasında femur başı epifizinin kan dolaşımı yoluyla gerçekleşen beslenmesinin bozulması olabilir.

\section{Retiküloendotelyal Sistem Hastalıkları}

Dilkaya toplumunda retiküloendotelyal sistem hastalıklarından biri olan multiple myelomaya da rastlanmıştır. Toplum genelinde bu patolojiye rastlanma oran $1 \% 0,31$ 'dir. Multiple myeloma, lenfosit (akyuvarlar) yapısının bozulmasıyla ortaya çıkan bir hastalıktır. Etiyolojisi bilinmemekle birlikte birçok vakada yapılan incelemelere göre 14. kromozomdaki anormallik sonucu ortaya çıktığı düşünülmektedir (Ortner, 2003; Aufderheide ve Rodriguez-Martin, 2006; Mann ve Hunt, 2012). Dilkaya toplumunda sadece yaşlı bir erkek bireyde multiple myelomaya rastlanmıştır. Toplumda bu hastalığa rastlanma nedeni genetik kaynaklı olabilir.

\section{Sonuç}

Dilkaya toplumunda yapilan incelemeler ve değerlendirmeler sonucunda şu sonuçlara ulaşılmıştır:

Toplumda gözlemlenen konjenital anomalilerin tamamı genetik kökenli anomalilerdir. Toplumda yedi farklı konjenital anomalinin, farklı frekanslarda görülmesinin temel nedeni soy içi/akraba evlilikleri nedeniyle bu anomalilere yol açan genlerin kalitım yoluyla aktarılmasıdır ve bu yapı Dilkaya Toplumu'nun kapalı ve görece homojen bir yapıya sahip olduğunu düşündürmektedir.

Dilkaya toplumundaki erişkin bireylerin dirsek ve omuz eklemlerinde yüksek osteoartrit ve claviculalarda rastlanan rhomboid fossa oranları, Dilkaya insanlarının özellikle erkeklerinin, yoğun günlük aktiviteleri arasında ağır yük kaldırma veya taşıma, kol gücüne dayalı ve yüksek efor gerektiren orak, tırpan gibi tarım aletlerinin kullanımı veya tohum serpme, anız kaldırma gibi tarımsal faaliyetler olduğunu işaret etmektedir. Dilkaya toplumundaki erişkin bireylerin özellikle bacak 
kemiklerinde gözlemlenen DFCE'nin ve entosopatilerin muhtemel nedeni ise ağır yük kaldırma veya karasaban, kızak, harman döveni, tırpan gibi kullanımı esnasında yüksek efor sarf edilmesini gerektiren ve çok uzun süre ayakta kalmayı zorunlu kılan tarım aletlerinin kullanımı olabilir.

Toplumda spondyloysis gibi bazı anomalilerin daha çok kadın bireylerde görülmesi belirli bir yaşa kadar bazı işlerin beraberce yapıldı̆̆ının bir göstergesi olabilir. Ancak erişkin erkek bireylerin yaşam biçimine bağlı patolojilerden yüksek oranda etkilenmeleri belirli bir yaştan sonra erkek bireylerin kadın bireylere göre daha yüksek efor gerektiren işlerde çalıştı̆̆ının bir göstergesi olabilir.

Gerek kafatası gerekse gövde kemiklerinde görülen travmalara diğer toplumlara kıyasla fazla karşılaşılmaması toplumun göreceli olarak "barışçıl" olduğunun bir göstergesi olabilir. Toplumda gözlemlenen travmalar muhtemelen günlük aktivite ve gündelik yaşamda karşılaşılan düşme, çarpma, vurma gibi küçük kazalarla ilișkili olmalıdır.

Dilkaya toplumunda demir eksikliği anemisine diğer toplumlara göre daha az rastlanması toplumun beslenme yapısının görece iyi olduğunun göstergesi olabilir. Ancak paleodemografik verilerdeki yüksek bebek-çocuk ölümlülüğü ve periostitin düşük frekansı durumun böyle olmayabileceğini, bireylerin enfeksiyonel hastalıklara yakalandıklarında hastalık henüz kemikte tahribata başlamadan, çok hızlı bir şekilde yaşamlarının sona ermiş olabileceğini de akla getirmektedir. Ancak bu konuda doğrudan bir kanıt elde edilememiştir. D vitamini eksikliğine bağlı lezyonların görece az olması da bireylerin güneş 1şığından yeteri kadar faydalandığını ve beslenme düzeylerinin yeterli olduğunu düşündürmektedir.

Tüm bu veriler 1şığında Dilkaya Orta Çağ Toplumu'nun tarıma dayalı bir ekonomiye sahip, fiziksel olarak erkeklerin daha ağır ve yoğun çalıştığı, beslenme açısından göreceli iyi durumda ve diğer Anadolu toplumlarına göre göreceli olarak daha hijyenik yaşam koşullarnna sahip bir köy topluluğu olduğu düşünülmektedir.

\section{Teşekkür}

Bu çalışmanın materyalini oluşturan Dilkaya iskeletleri üzerinde çalışmama izin veren, akademiye girdiğim ilk zamanlardan beri ihtiyaç duyduğum her an yanımda olan doktora danıșmanım Prof. Dr. Erksin Güleç'e teșekkür ederim.

\section{Kaynakça}

Aksoy, M. C., Yazıc1, M., ve Alpaslan, M. (2005). LeggCalve-Perthes Hastalı̆g1, TOTBID (Türk Ortopedi ve Travmatoloji Birliği Derneği) Dergisi, 4(3-4), 138-148.
Altuntek, S., N. (2001). Türkiye Üzerine Yapılmıș Evlilik ve Akrabalık Araştırmalarının Bir Değerlendirmesi, Hacettepe Üniversitesi Edebiyat Fakülttesi Dergisi, 18(2), 17-28.

Angel, J. L. (1971). Early Neolithic Skeletons from Catal Hüyük: Demography and Pathology, Anatolian Studies, 21, 77-98. 10.2307/3642632

Angel, J. L., ve Bisel, S. C. (1986). Health and Stress in an Early Bronze Age Population. in J. V. Canby, E. Porada, B. S. Ridgeway, T. Stech (Eds.) içinde, Ancient Anatolia: Aspects of Change and Cultural Development. Essays in Honor of Macbteld M. Mellink (s. 12-30), Wisconsin: University of Wisconsin Press.

Arıhan Karaöz, S., ve Acar, E. (2014). Giresun Adası İskeletlerinin Paleoantropolojik Değerlendirilmesi, T.C. Kültür ve Turizm Bakanliğ Kültür Varlkklar ve Müzeler Genel Müdürlï̈̆̈̈ XXX. Arkeometri Sonuclar Toplantisi, 189-202.

Ay, N. (2014). Müslümantepe Iskeletlerinin Paleopatolojik Açıdan Analizi, Ankara Üniversitesi Sosyal Bilimler Enstitüsü, Basılmamış Yüksek Lisans Tezi, Ankara.

Aufderheide, C. A. ve Rodriguez-Martin, C. (2006). The Cambridge Encyclopedia of Human Paleopathology, Birleşik Krallık: Cambridge University Press.

Belli, O., ve Konyar, E. (2003). Doğu Anadolu Bölgesinde Erken Demir Cağı Kale ve Nekropolleri, İstanbul: Arkeoloji ve Sanat Yayınları.

Brothwell, D. R. (1981). Digging Up Bones (Third Edition). Birleşik Krallık: British Museum - Oxford University Press.

Blau, S. (2001). Limited Yet Informative: Pathological Alterations Observed on Human Skeletal Remains from Third and Second Millennia BC Collective Burials in the United Arab Emirates, International Journal of Osteoarchaeology, 11, 173-205 10.1002/ oa.527

Brickley, M., ve Ives, R. (2008). The Bioarchaeology of Metabolic Bone Disease, Elsevier Academic Press.

Buikstra, J. E. ve Ubelaker, D. H. (1994). Standarts for Data Collection from Human Skeletal Remains, Arkansas: Arkansas Archeological Survey.

Buikstra, J. E. (2019), Ortner's Identification of Pathological Conditions in Human Skeletal Remains (Third Edition). Birleşik Krallık: Academic Press.

Büyükkarakaya A. M., ve Erdal Y. S. (2012). Eski Anadolu Toplumlarında Anemi, Biyolojik Antropoloji, Ankara Üniversitesi Dil ve Tarih-Coğrafya Fakültesi 75. Kuruluş Y1ldönümü Anı Kitab1, A.Ü. D.T.C.F Yayınları, 137-162. 
Çırak A., Çırak M. T., ve Atasoy, Y. S., (2014), İnsan İskelet Kalıntılarında vertebral Ankylosis: Tios İskeletleri Üzerinde Bir Çalışma, T.C. Kültür ve Turizm Bakanlĭg Kültür Varlkelar ve Müzeler Genel Müdürlügü̈ 28. Arkeometri Sonuclarn Toplantısı, 51-58.

Çilingiroğlu, A. (1986). Van Dilkaya Höyüğü 1984 Kazıları, T.C. Kültür ve Turiżm Bakanlĭg Eski Eserler ve Müzeler Genel Müdürlüğ̈ VII. Ką̧ Sonuclar Toplantisi, 151-162.

Çilingiroğlu, A. (1990). Van-Dilkaya Höyügü Kazıları 1988, T.C. Kültür Bakanlığ1 Anttlar ve Müzeler Genel Müdürlüğü XI. Kazı Sonuçları Toplantısı I, 247-254.

Çilingiroğlu, A. (1993). Van-Dilkaya Höyüğü Kazıları Kapanış, T.C. Kültür Bakanlğ̆ Anttlar ve Müzeler Genel Müdürlügü XIV. Kąı Sonuclar Toplantısı I, 469489.

Çilingiroğlu, A. (1994). Yeni Urartu Kazılarına Doğru, XI. Türk Tarih Kongresi I, 279-286.

Çilingiroğlu, A. (1997). Urartu Kralluğ Taribi ve Sanatı, İzmir: Yaşar Eğitim ve Kültür Vakfi.

Çilingiroğlu, A. (2012) Dilkaya Höyüğü, Ege Üniversitesi Arkeoloji Kazllar (s. 78-93). İzmir: Ege Üniversitesi.

Digangi, E. A, Bethard, J. D., ve Sullivan, L. P. (2010). Differential Diagnosis of Cartilaginous Dysplasia and Probable Osgood-Schlatter's Disease in a Mississippian Individual from East Tennessee, International Journal of Osteoarchaeology, 20, 424-442. 10.1002/oa.1062

Ellis, H. (2006). Clinical Anatomy A Revision and Applied Anatomy for Clinical Students, ABD: Blackwell Publishing.

Erdal Ö. D., Erdal Y. S., Eroğlu S., ve Büyükkarakaya A. M. (2003). Şaşal/İzmir İskelet Topluluğunun Paleopatolojik ve Demografik Analizi, Kültür Bakanlĭg Anttlar ve Müzeler Genel Müdürlü̈̆̈̈ XVIII. Arkeometri Sonuclar Toplantısi, 1-14.

Erdal, Ö. D. (2004). Eklem Hastahklarmm Yaşam Biçimiyle İliskisi: Eski Anadolu Topluluklar Örneği, Hacettepe Üniversitesi Sosyal Bilimler Ensitütüsü Basılmamış Doktora Tezi.

Erdal Ö. D. (2009). Demre Aziz Nikolaos Kilisesi Geç Bizans ve Yakınçağ İnsanlarının Yaşam Biçimleri, Adalya, XII, 361-388.

Erdal, Y. S. (2003). Büyüksaray-Eski Cezaevi Çevresi Kazılarında Gün Işı̆̆ına Çıkarılan İnsan İskelet Kalıntılarının Antropolojik Analizi, T. C. Kültür Bakanlĭgr Anttlar ve Müzeler Genel Müdürlüğ̈̈ XVIII. Arkeometri Sonuçar Toplantısi, 15-30.
Erdal, Y. S. (2004). Kovuklukaya (Boyabat, Sinop) İnsanlarının Sağlık Yapısı ve Yasam Biçimleriyle İlişkisi, Anadolu Araștrmalar, 17(2), 169-196.

Erdal, Y.S. (2011). EK1: Tasmasor Yakınçağ Nekropolü ve İskeletlerinin Antropolojik Analizi, S. Y. Şenyurt (Ed.), içinde, Tasmasor (s. 255-359). Ankara: Bilgin Yayınları.

Erkman, A. C. (2008). Van Dilkeaya Erken Demir Căğ ve

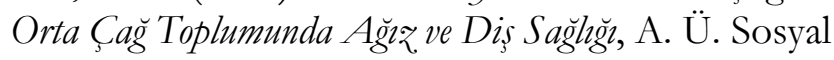
Bilimler Enstitüsü, Basılmamış Doktora Tezi, Ankara.

Erkman A. C., Başoğlu, O., Özgün-Başıüyük, G., Gözlük-Kırmızığlu, P., Yiğit, A., Alkan-Yalçın, Y., ve Kaya, F. (2016). Cranial And Post-Cranial Traumatic Injury Patterns In Van Castle Mound Medieval Population, Mediterranean Archaeology and Archaeometry, 16(2), 61-74. 10.5281/zenodo.47543

Gözlük P., Durgunlu, Ö., Özdemir, S., Taşlıalan M., ve Sevim A. (2006). Symrna Agoras1 İskeletlerinin Paleoantropolojik Analizi, Kültür ve Turizm Bakanlĭgr Kültür Varlıklarn ve Müzeler Genel Müdürlügü XXI. Arkeometri Sonuclar Toplantısi, 125-140.

Güleç, E. (1986). Van-Dilkaya İskeletlerinin Paleoantropolojik İncelenmesi, T. C. Kültür ve Turizm Bakanlĭgr Eski Eserler ve Müzeler Genel Müdürlügü IV. Arasstırma Sonuclar Toplantisı, 369-380.

Güleç., E. (1989). Paleoanthropological Structure of Van / Dilkaya Dwellers: B.C. First Millenium - A.D. First Millenium, Humanbiologia Budapestinensis, 19, 47-52.

Güleç, E., Duyar, İ., ve Sevim, A. (1993). Eski Anadolu toplumlarında Büyüme (II): Dilkaya Orta Çağ Populasyonu'nda Uzun Kemik Büyümesi, T. C. Kültür Bakanlĭgr Anttlar ve Müzeler Genel Müdürlügü XIII. Arkeometri Sonuclar Toplantısi, 227-241.

Güleç, E., ve Özer, İ. (2009). Dilkaya Ortaçă̆ İskeletlerinin Paleoantropolojik Analizi, $\mathrm{H}$. Sağlamtimur, E. Abay, Z. Derin, A. Ü. Erdem, A. Batmaz, F. Dedeoğlu, M. Erdalkıran, M. B. Baştürk ve E. Konakç1 (Ed.) içinde, Altan Çilingiroğlu'na Armağan: Yukar Deniz̨in Kiyısında Urartu Krallğ̆ı'na Adanmıs Bir Hayat, İstanbul: Arkeoloji ve Sanat Yayınları.

Günay I. (2005). Mersin - Kelenderis (19.YY) Toplumunun Sağhlk Sorunlar, A. Ü. Sosyal Bilimler Enstitüsü, Basılmamış Yüksek Lisans Tezi, Ankara.

Jurmain, R. D. (1977). Stress and the Etiology of Osteoarthritis, American Journal of Physical Anthropology, 46, 353-366.10.1002/ajpa.1330460214 
Jurmain, R. D. (1991). Degenerative Changes in Peripheral Joints as Indicators of Mechanical Stress: Opportunities and Limitations. International Journal of Osteoarchaeology, 1(3-4), 247-252. 10.1002/ oa.1390010319

Kalelioğlu, E. (1991). Van Ovasının İklim Özellikleri, A.Ü. D.T.C.F. Dergisi, 35(2), 155-166.

Kilıç, O. (1997). XVI. ve XVII. Yüzynllarda Van (15481648), Van Belediye Başkanllğ1 Kültür ve Sosyal İşler Müdürlüğü Yayın No: 6, Ankara: Acar Matbaası.

Knüsel, C. J., Göggel, S., ve Lucy, D. (1997). Comparative Degenerative Joint Disease of the Vertebral Column in the Medieval Monastic Cemetery of the Gilbertine Priory of St. Andrew, Fishergate, York, England, American Journal of Physical Anthropology, 103, 481-495. 10.1002/ (SICI) 1096-8644(199708)103:4<481::AIDAJPA6>3.0.CO;2-Q

Koruyucu, M. M. (2012). Kösk Höyük Ortaçăg İnsanlarmmn Antropolojik Analizi, Hacettepe Üniversitesi Sosyal Bilimler Enstitüsü, Basılmamış Yüksek Lisans Tezi, Ankara.

Köroğlu K., ve Konyar, E. (2005). Van Gölü Havzasında Erken Demir Çă̆ı Problemi, Arkeoloji ve Sanat, 119, 25-38.

Köroğlu K., ve Konyar, E. (2008). Comments on the Early/Middle Iron Age Chronology of Lake Van Basin, Ancient Near Eastern Studies, 45, 123-146.

Kutlubay, A. (2007). Malatya İlinde Akraba Evliliği Sıkil̆ğ ve Tıbbî Sonuclar, İnönü Üniversitesi Sağlık Bilimleri Enstitüsü Basılmamış Yüksek Lisans Tezi, Malatya.

Larsen, C. S. (1997) Bioarchaeology: Interpreting Behavior from the Human Skeleton, Cambridge: Cambridge University Press.

Lessa, A. (2011) Spondylolysis and Lifestyle Among Prehistoric Coastal Groups From Brazil, International Journal of Osteoarchaeology, 21, 660-668. 10.1002/ oa.1172

Lovell, N. C. (1994). Spinal Arthritis and Physical Stress at Bronze Age Harappa, American Journal of Physical Anthropology, 93, 149-164.10.1002/ajpa.1330930202

Lovell, N. C. (1997). Trauma Analysis in Paleopathology, Yearbook of Physical Anthropology, 40, 139-170. 10.1002/(SICI) 1096-8644(1997)25+<139::AIDAJPA6>3.0.CO;2- $\% 23$

Lovell, N. C. (2008). Analysis and Interpretation of Skeletal Trauma. M. A. Katzenberg ve S. R. Saunders (Ed.) içinde, Biological Anthropology of the Human Skeleton (s. 341-386), New York: Wiley-Liss. 10.1002/9780470245842.ch11
Mann R. W., ve Hunt D. R. (2012). Photographic Regional Atlas of Bone Disease: A Guide To Pathologic And Normal Variation in the Human Skeleton (Third Edition). Springfield Illinois: Charles C. Thomas Publisher.

Mann R.W., Hunt D.R., ve Lozanoff, S. (2016). Photographic Regional Atlas of Non-Metric Traits and Anatomical Variants in the Human Skeleton (First Edition), Springfield Illinois: Charles C. Thomas Publisher.

Merbs, C. F. (1983). Patterns of Activity-Induced Pathology in a Canadian Innit Population, Ottawa: National Museum of Man Mercury Series.

Molleson, T., ve Hodgson, D. (2003). The Human Remains from Woolley's Excavations at Ur, Iraq, 65, 91-129. 10.2307/4200535

Ortner, D. J. (2003). Identification of Pathological Conditions in Human Skeletal Remains (Second Edition). San Diego, CA: Academic Press.

Ökten, Ş. (2009). Toplumsal Cinsiyet ve İktidar: Güneydoğu Anadolu Bölgesi'nin Toplumsal Cinsiyet Düzeni, Uluslararası Sosyal Arastırmalar Dergisi, 2(8), 302-312

Özdemir, S., Sevim Erol, A. (2010). Minnetpınar1 İskeletlerinin Paleopatolojik Açıdan Analizi, Antropoloji, 23, 95-127.

Özbek, M. (2012) Kronik Demir Eksikliğine Bağlı Anemi: Klinik ve Paleopatolojik Bulgular Işığında Yeni Değerlendirmeler, A. A. Akyol ve K. Özdemir (Ed.) içinde, Türkiye'de Arkeometrinin Ulu Çmarlar Prof. Dr. Ay Melek Özer ve Prof. Dr. Şabinde Demirci'ye Armağan Kitabı, İstanbul: Homer Kitabevi.

Paine, R. R., Vargiu, R., Coppa, A., Morselli, C., ve Schneider, E. E. (2007). A Health Assessment of High Status Christian Burials Recovered From The Roman-Byzantine Archaeological Site of Elaiussa Sebaste, Turkey, HOMO, 58, 173-190. 10.1016/j. jchb.2006.06.001

Plichta, S.B., ve Kelvin, E. (2014). Munro Sağhke Araștırmalarnda Istatistiksel Yöntemler. R. S. Tabak (Çev. Ed.), Ankara: Palme Yayıncılık.

Resnick, D., ve Niwayama, G. (1988). Degenerative Disease of The Spine, D. Resnick ve G. Niwayama (Ed.) içinde, Diagnosis of Bone And Joint Disorders (s. 1481-1561), Philadelphia: W. B. Saunders Company.

Roberts, C., ve Manchester, K. (2007). The Archaeology of Disease (Third Edition). Ithaca, NY: Cornell University Press. 
Sağır, M., Özer, İ., ve Şahin, S. (2018). Havuzdere İskeletlerinin Paleopatolojik Analizi, T.C. Kültür ve Turizm Bakanliğ XXXV. Arasstorma Sonuclar Toplantısi, II. Cilt, 127-142.

Sar1-Özdemir, C. (2004). Dilkaya ve Karagündür (Orta Căg) Iskelet Popülasyonlarnda Doğustan Anomalilerin İncelenmesi, A.Ü. Sosyal Bilimler Enstitüsü, Basılmamış Yüksek Lisans Tezi, Ankara.

Schug, G. R., Gray, K., Mushrif-Tripathy, V., ve Sankhyand, A. R. (2012) A peaceful realm? Trauma and social differentiation at Harappa, International Journal of Paleopathology, 2, 136- 147. 10.1016/j. ijpp.2012.09.012

Sevim, A., Gözlük Kırmızıŏlu, P., Yiğit A., Özdemir S., ve Durgunlu Ö. (2007). Erzurum/ Güllüdere İskeletlerinin Paleoantropolojik Açıdan Değerlendirilmesi, T.C. Kültür ve Turizm Bakanluğr Kültür Varlıklar ve Müzeler Genel Müdürlüğ̈ XXII. Arkeometri Sonuclar Toplantısi, 141-160,

Sevin, V., ve Kavakl1, E. (1996). Bir Erken Demir Că̆ Nekropolü Van/Karagündüz, İstanbul: Arkeoloji ve Sanat Yayınları.

Taylor, J. A. M., ve Resnick, D. (2010). Skeletal Imaging: Atlas of the Spine and Extremeties (Second Edition). Philadelphia: Saunders.

Üstündağ, H., ve Demirel, F. A. (2008). Alanya Kalesi Kazılarında Bulunan İnsan İskelet Kalıntılarının Analizi, Türk Arkeoloji ve Etnografya Dergisi, 8, 79-90.

Üstündağ, H. (2009). Kuşadası Kadıkalesi / Anaia Kazısinda Bulunan İnsan İskelet Kalıntıları, T.C. Kültür ve Turizm Bakanliğ Kültür Varllklar ve Müzeler Genel Müdürlügü XXIV. Arkeometri Sonuclar Toplantısı, 209-228.

Üstündağ, H. (2011). Genetik, Çevresel ve Kültürel Etmenlerin Işı̆̆ında Anemi: Bazı Eski Anadolu Topluluklarından Örnekler, Turkish Academia of Sciences Journal of Archaeology, 14,173-192.10.22520/ tubaar.2011.0014

Waldron, T. (2009). Palaeopathology, Cambridge: Cambridge University Press.

Wentz, R. K., ve De Grummond, N. T. (2009). Life on Horseback: Palaeopathology of Two Scythian Skeletons from Alexandropol, Ukraine, International Journal of Osteoarchaeology, 19, 107-115. 10.1002/ oa.964

Yüksel, S.., Kutlubay, A., Karaoğlu, L., ve Yoloğlu, S. (2009). The Prevalence of Consanguineous Marriages in the City of Malatya, Turkey, Turk. J. Med. Sci., 39(1), 133-137, 10.3906/sag-0802-7 